\title{
Conservação da coleção de álbuns fotográficos do Museu da Imagem e do Som de Goiás
}

\author{
Stela Horta Figueiredo ${ }^{1}$ \\ Maria Clara Mosciaro ${ }^{2}$ \\ Ivy da Silva ${ }^{3}$
}

RESUMO: $\bigcirc$ artigo tem como objeto o tratamento de conservação da coleção de álbuns fotográficos do Museu da Imagem e do Som de Goiás, realizado com recursos provenientes da Fundação Vitae, em parceria com o Centro de Conservação e Preservação Fotográfica da Funarte. Apresentamos, com referência a cada álbum fotográfico, informações históricas, uma descrição sumária, as características de deterioração, os procedimentos adotados e as principais intervenções realizadas durante o tratamento de conservação.

PALAVRAS-CHAVES: Conservação. Fotografia. História de Goiânia.

ABSTRACT: This paper discusses the conservation of a collection of photographic albums belonging to the Goiás Image and Sound Museum, which was carried out with Vitae Foundation funding and in partnership with Funarte's Center for Photographic Conservation and Preservation. The authors present a brief description of each photographic album along with historical data and information about their state of deterioration, as well as the procedures adopted and the main interventions performed during their conservation.

KEYWORDS: Conservation. Photography. History of Goiânia.

A coleção de álbuns fotográficos ${ }^{4}$ do Museu da Imagem e do Som de Goiás ${ }^{5}$ doravante MIS-GO, é constituída por um dos mais importantes conjuntos de imagens com valor histórico existentes no Acervo Fotográfico dessa Instituição. São 880 fotografias, que compreendem o período de 1930 a 1950, época que corresponde, aproximadamente, à de construção de Goiânia'. Cabe ressaltar que Goiânia foi uma cidade planejada e construída após a Revolução de 1930, no contexto da política desenvolvimentista do governo Vargas, durante o Estado
1. Do Museu da Imagem e do Som de Goiás, Praça Dr. Pedro Ludovico Teixeira, $\mathrm{n}^{\circ} 2$, Centro - 74.003-010 - Goiânia - GO. E-mail: <stelahf@ uol.com.br>.

2. Do Centro de Conservação e Preservação Fotográfica da Funarte.

3. Do Centro de Conservação e Preservação Fotográfica da Funarte

4. Consideramos "álbum Fotográfico" como um conjunto de folhas reunidas, onde são fixadas imagens fotográficas; no caso da coleção considerada, trata-se de álbuns com originais fotográficos (Cf. FUNARTE-IBAC, 1993)

5. O Museu da Imagem e do Som de Goiás é uma unidade daAgência Goiana de Cultura Pedro Ludovico Teixeira, órgão do governo estadual responsável pela gerência da cultura em Goiás.

6. Goiânia foi fundada em 24 de outubro de 1933 e conservou praticamente a mesma estrutura urbana prevista no Plano Urbanístico de 1938 (Cordeiro, 1989). Por isso é consenso entre os autores da historiografia goianiense considerar o período 
1933-1950 como correspondendo à "construção de Goiânia”.

7. Fizeram parte da equipe de trabalho no CCPF-Funarte: Maria Clara Mosciaro (historiadora e conservadora), Ivy da Silva (conservadora), Richam Samir (fotógrafo e arquivista), Gerana de Holanda (laboratorista) e Sandra Calixto (encadernadora)

8.Trabalharam na segunda fase do projeto no MIS-GO:Stela Horta Figueiredo (fotógrafa e conservadora), Keith Tito (historiadora) e Sejana de Pina Jayme (estudante de Artes Visuais).

9. O projeto Pioneiros da Fo tografia em Goiânia foi desenvolvido de janeiro de 2001 a agosto de 2002, pela equipe do MIS-GO,com o objetivo de constituir um acervo da vida e da obra dos primeiros fotógrafos da cidade. A publicação dos volumes dois e três da série Cadernos de Fotografia do MIS, a realização de uma exposição fotográfica, 16 entrevistas transcritas e digitalizadas, incorporadas à documentação do acervo e 1260 documentos fotográficos doados por familiares e amigos dos fotógrafos constituíram alguns dos resultados do projeto.
Novo. As imagens não se restringem à capital: também fazem parte do conjunto registros significativos dos principais municípios goianos.

A nova capital, em construção, constituía um foco de atração para trabalhadores de níveis e categorias profissionais diferentes, vindos de outros estados do Brasil. Os primeiros fotógrafos chegavam a Goiânia ideologicamente motivados por idéias de progresso e modernidade, mas também por metas mais concretas, como a melhoria das condições de vida e de trabalho. Orientados por exigências da clientela e do mercado, os fotógrafos não se limitavam à produção de retratos de pessoas e de grupos familiares em estúdios: documentavam eventos sociopolíticos, festividades, registravam a construção das avenidas e dos edifícios, e o surgimento da vida urbana no ambiente inóspito do cerrado goiano.

Até 2004, o estado de conservação da coleção de álbuns impossibilitava a realização de pesquisas, exposições, publicações e projetos educativos de dimensão museológica, pois os documentos estavam com sua estrutura física comprometida: os papéis suporte, os entrefolhamentos e as fotografias apresentavam-se em avançado estágio de deterioração.

O tratamento de conservação foi possível por meio de projeto desenvolvido em parceria com o Centro de Conservação e Preservação Fotográfica da Funarte (CCPF-RJP', com recursos provenientes da Fundação Vitae. A primeira fase do projeto, envolvendo o tratamento de conservação, a reprodução fotográfica e o treinamento de uma técnica do MIS-GO em técnicas de estabilização e consolidação fotográfica, foi realizada na sede do CCPF-RJ durante o ano de 2005; a segunda fase teve início em março de 2006, no MIS-GO ${ }^{8}$, logo após a chegada dos álbuns já tratados em Goiânia, e compreendeu atividades de pesquisa histórica, catalogação, digitalização dos negativos e inserção das imagens no Banco de Dados Informatizado.

Os álbuns integram três coleções: Luiz Pucci, Museu Estadual Prof. Zoroastro Artiaga, e José Mendonça Teles. Apresentamos a seguir, para cada álbum fotográfico, informações históricas, uma descrição sumária, as características de deterioração e as principais intervenções realizadas durante o tratamento de conservação. Cabe ainda acrescentar que todas as fotografias são em preto e branco, e apresentam a mesma estrutura física: suporte de papel, tendo gelatina como camada emulsionante e prata como substância formadora da imagem.

Álbum da Coleção Luiz Pucci

O álbum integra um conjunto de documentos fotográficos, constituído por fotografias em preto e branco e negativos flexíveis, doado por Hilda Pucci, esposa do fotógrafo pioneiro Luiz Pucci (17.1.1919 - 20.10.1978), em 2002, quando o MIS-GO desenvolvia o projeto Pioneiros da Fotografia em Goiânia?. 
No início da década de 1950, o fotógrafo e a esposa organizaram o álbum para servir de mostruário de poses para os clientes no estúdio. Hilda foi companheira e ajudante do fotógrafo. Com muito capricho, fazia o "colorido à mão" nas fotografias e montava a vitrina com as fotografias mais "artísticas" e com os álbuns que serviam como mostruário de poses. Preocupado com a conservação desses álbuns, Pucci fazia a seguinte inscrição na contracapa: "Favor me olhar com cuidado". Também carimbava no verso das fotos a frase: "Esta fotografia foi roubada do mostruário de Pucci Fotógrafo", para intimidar as pessoas que quisessem retirar alguma imagem como lembrança.

O álbum é constituído por 246 retratos, sendo 41 deles coloridos "à mão"; a maioria das fotos é produzida em estúdio, com poses de homens, mulheres, casais de noivos, casais com filhos e crianças (Figura 1). $\bigcirc$ retrato de uma jovem, tamanho $20 \times 25 \mathrm{~cm}$, colorizado "à mão", é emoldurado no centro da capa e recoberto por acetato. A moldura de couro, semelhante a um passepartout, apresentava desgaste e acabamento comprometido, com as costuras e

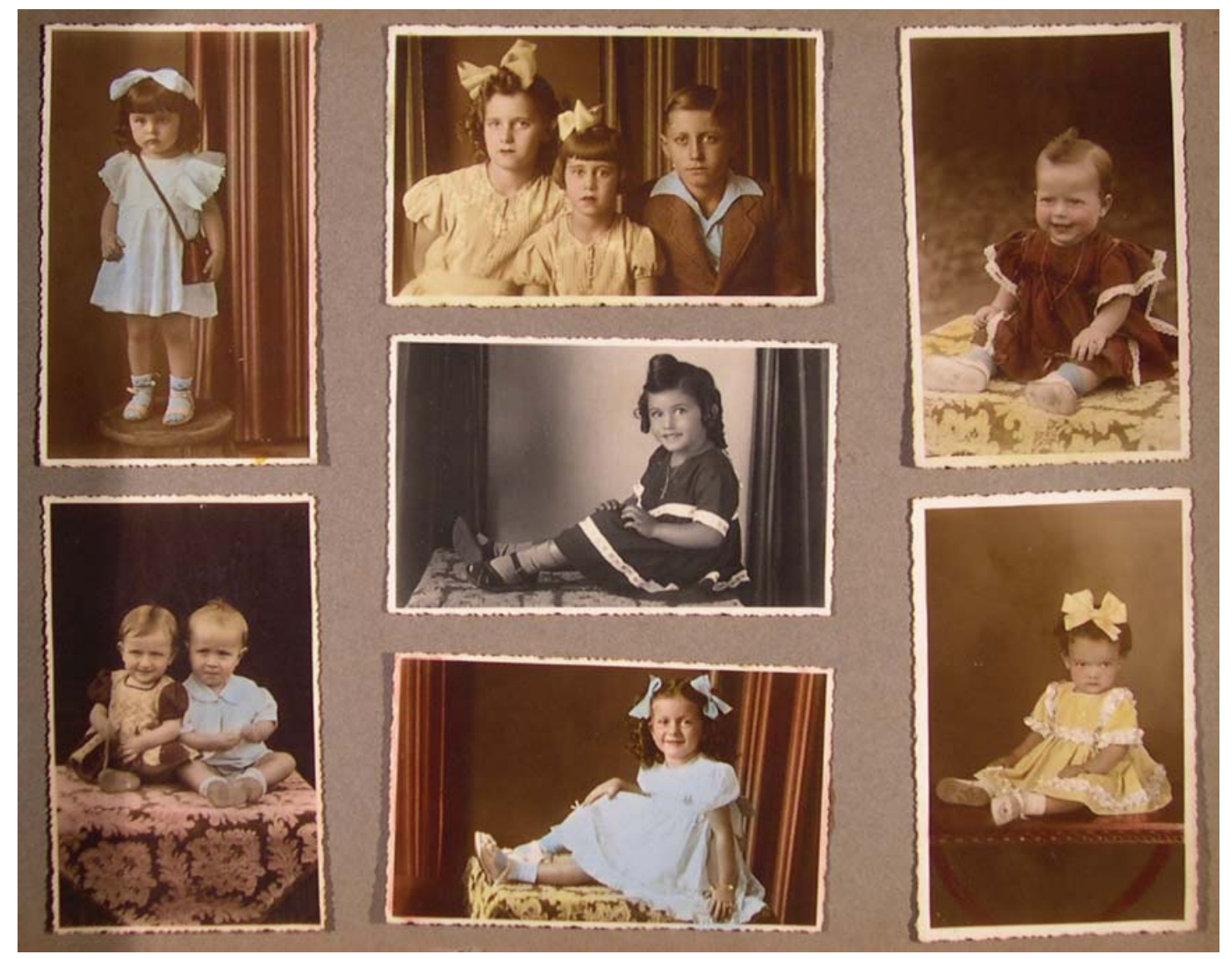

Figura 1 - Página do álbum da Coleção Luiz Pucci com fotografias coloridas "à mão". Acervo do Museu da Imagem e do Som de Goiás, Goiânia. Reprodução de Richam Samir, 2005. 
10. No tratamento do álbum da Coleção Pucci foram empregadas medidas de conservação e de restauro. Convém aqui explicitar que o tratamento envolveu dois objetos de conservação, o álbum fotográfico e os originais fotográficos em seu interior. Em relação às fotografias não se requer propriamente restauração, mas medidas de conservação,para preservar suas imagens. Segundo Luis Pavão,"o restauro não tem em fotografia tanta importância como noutros setores da conservação". Procura-se até mesmo conservar as marcas visíveis da ação do tempo, reparando materiais que sofreram danos físicos, o que vem a constituir uma forma de estabilização (Cf. PAVÃO, 2004 , p. 11). Contudo, a situação é diferente no que concerne aos álbuns fotográficos como objetos museológicos.A medida de substituir as páginas de suporte interfere, certamente, na "materialidade" do álbum. Contudo, tal medida torna-se plausível quando o suporte coloca em risco a fotografia (Cf. MUSEUMS, LIBRARIES AND ARCHIVES COUNCIL, 2005, p. 43). O Museu da Imagem do Som privilegia, evidentemente, o valor histórico das imagens e sua relevância na memória coletiva em relação ao valor histórico do objeto que as contém, no caso, o álbum fotográfico, numa situação limite em que as condições de preservação da imagem estejam ameaçadas.Ainda assim, pode-se dizer que preservamos o atributo de "documento histórico", no sentido que lhe confere Ulpiano Menezes (1998, p. 9394), às fotografias e também aos álbuns, já que efetivamos medidas de conservação e restauração que garantem a ambos a condição de "suportes de informação" no âmbito das ações museológicas de pesquisa, preservação e comunicação. os arremates rompidos (Figura 2). A capa, também de couro, estava ressecada e encontrava-se separada do corpo do álbum. As páginas, de papel cartão cinza, de baixa qualidade, já apresentavam manchas escuras e sinais de acidez; algumas estavam quebradiças; o entrefolhamento, de papel manteiga, estava amarelecido e fragilizado (Figura 3).

A proposta de intervenção neste álbum foi amplamente discutida entre as conservadoras e a equipe técnica do acervo fotográfico do MIS-GO, pois envolveu a remoção das fotografias e a substituição do suporte original. A fragilidade e o estágio de deterioração do suporte tornariam qualquer intervenção de conservação pouco efetiva, comprometendo a estabilização das fotografias ${ }^{10}$. Por isso foram adotados, primeiramente, procedimentos que garantissem o

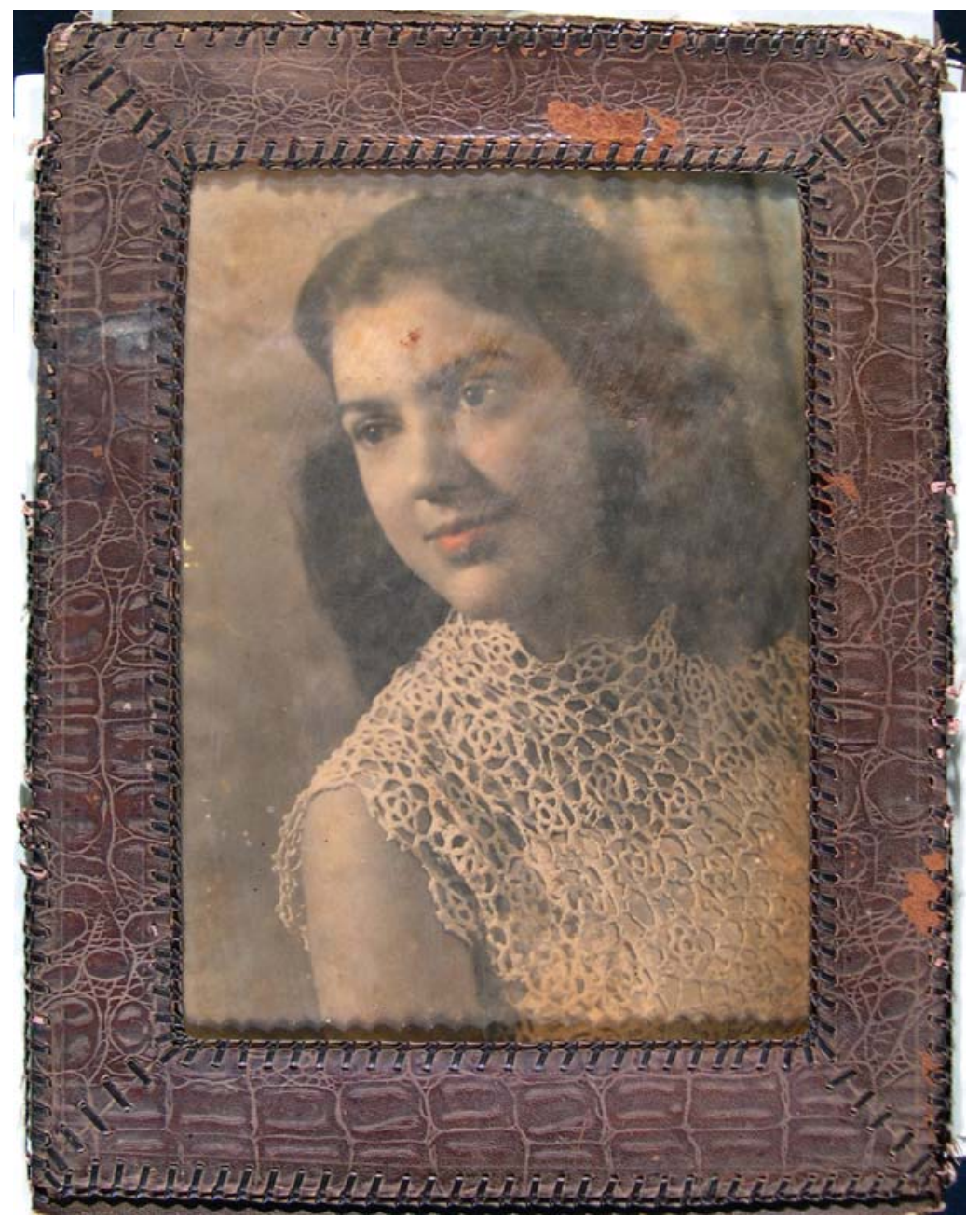

Figura 2 - Moldura de couro apresentando desgaste e acabamento comprometido. Acervo do Museu da Imagem e do Som de Goiás, Goiânia. Reprodução de Richam Samir, 2005. 


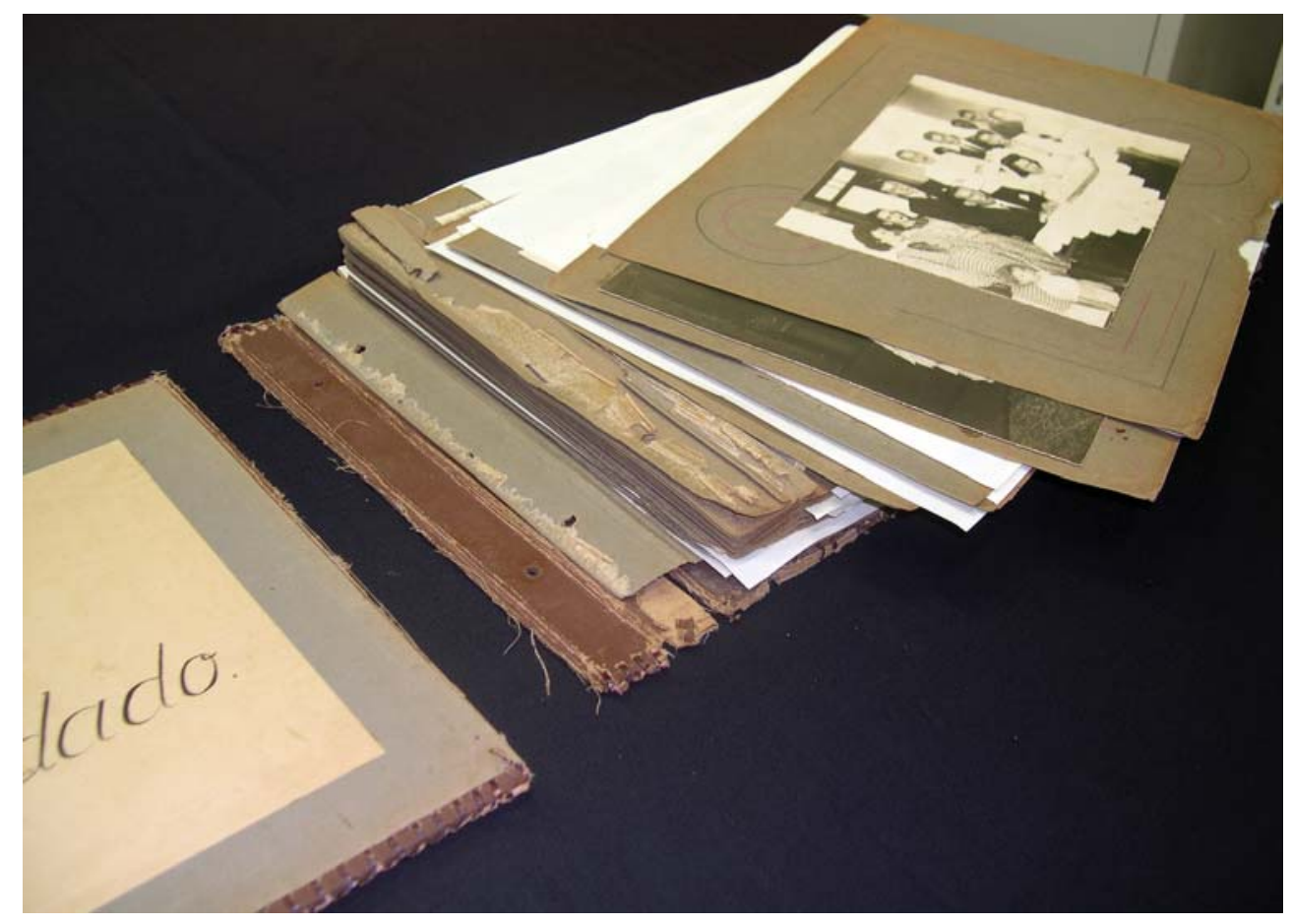

Figura 3 - Capa separada do corpo do álbum e folhas em papel cartão quebradiças e com sujidades. Acervo do Museu da Imagem e do Som de Goiás, Goiânia. Fotografia de Richam Samir, 2005.

reposicionamento das fotografias conforme sua apresentação original: registro fotográfico detalhado, página a página; mapeamento gráfico de todo o conjunto e numeração das fotografias. A seguir foi realizada a remoção mecânica das fotografias, que estavam afixadas com adesivo à base de goma arábica. Os resíduos de papel e cola remanescentes no verso das fotografias foram removidos com aplicação de metilcelulose. As fotografias foram higienizadas com trincha e esponja química e, de acordo com o estado de conservação de cada uma delas, pequenos reparos foram realizados.

A capa foi encaminhada à encadernadora Sandra Calixto, que recuperou a encadernação em couro e substituiu os arremates, que se encontravam completamente deteriorados. $\bigcirc$ acetato deteriorado que recobria a foto da capa foi substituído por folha de poliéster, promovendo uma melhora na visibilidade da imagem (Figura 4). Para o novo corpo do álbum, foi escolhido papel de cor, gramatura e textura semelhantes ao do original (Gainsborough, cor Charcoal, 240 g) (Figura 5). O entrefolhamento anterior, em papel de seda texturizado, foi substituído por papel japonês de baixa gramatura e tom amarelado (silk tissue).

Houve a remoção da folha de papel com a recomendação "Favor me olhar com cuidado", para um tratamento químico com água deionizada e solução de hidróxido de cálcio, visando a desacidificação (Figuras 6 e 7). Depois de seca e planificada, a folha retornou à contracapa do álbum recomposto (Figura 8). 


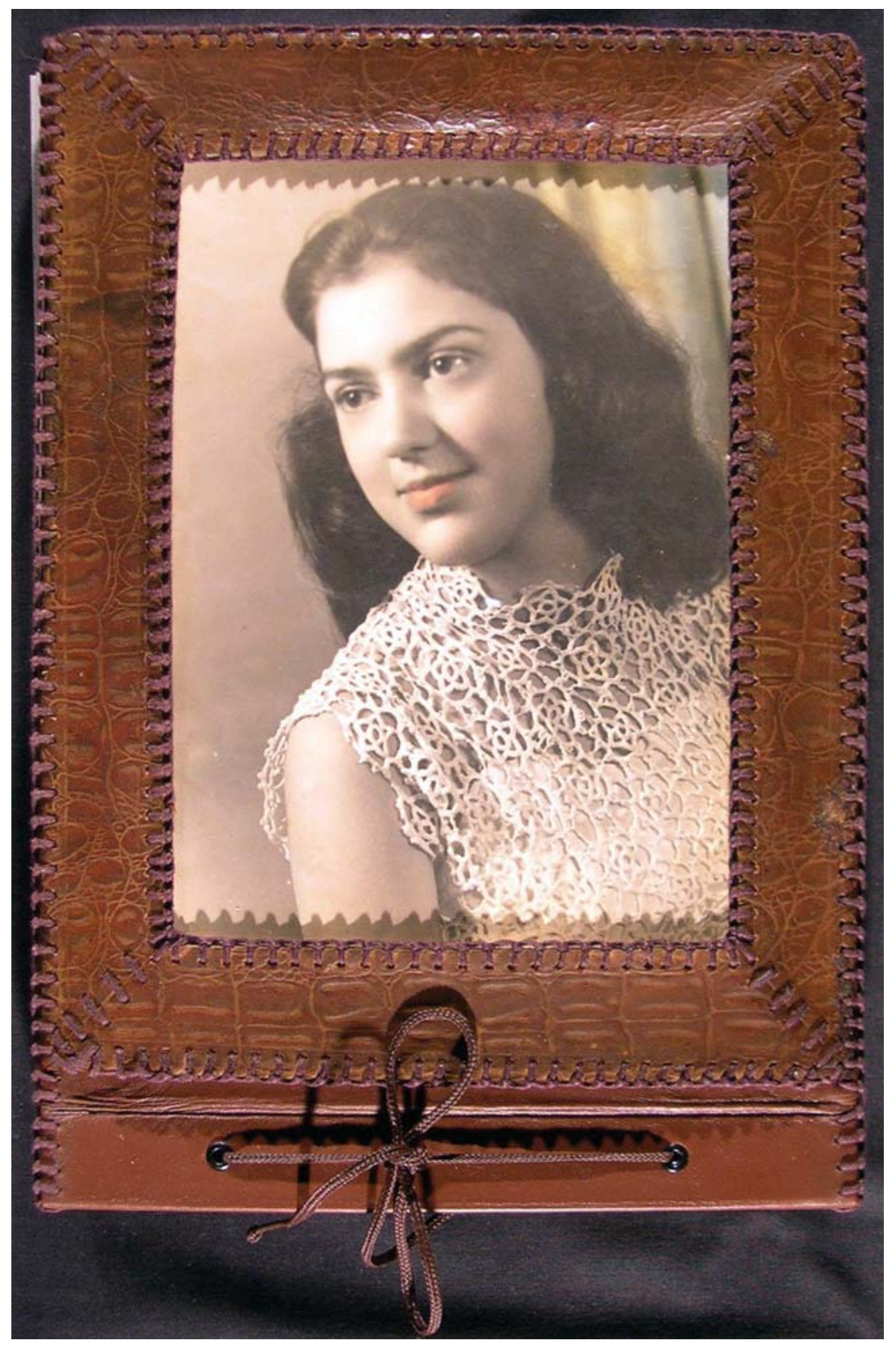

Figura 4 - Capa e fotografia após o tratamento de conservação. Acervo do Museu da Imagem e do Som de Goiás, Goiânia. Reprodução de Richam Samir, 2005. 


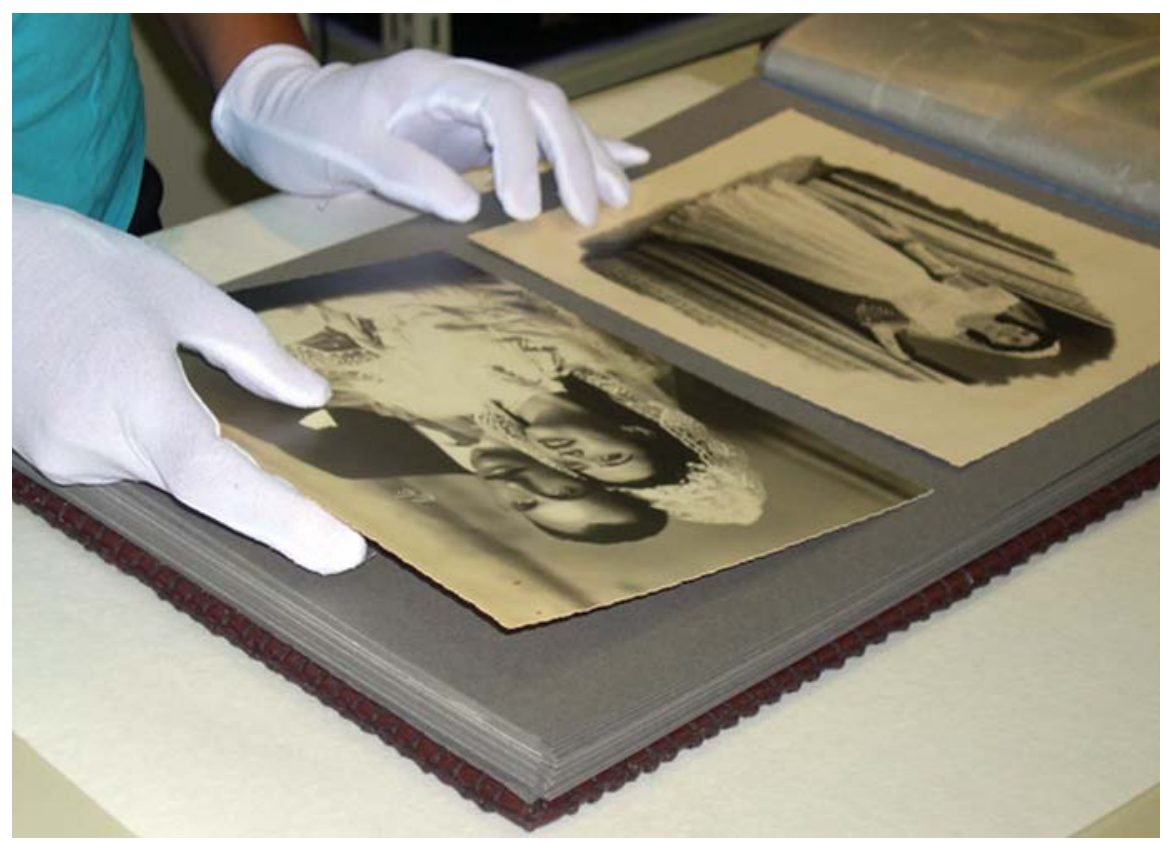

Figura 5 - Reposicionamento das fotografias após a substituição do corpo do álbum da Coleção Luiz Pucci. Acervo do Museu da Imagem e do Som de Goiás, Goiânia. Fotografia de Richam Samir, 2005.

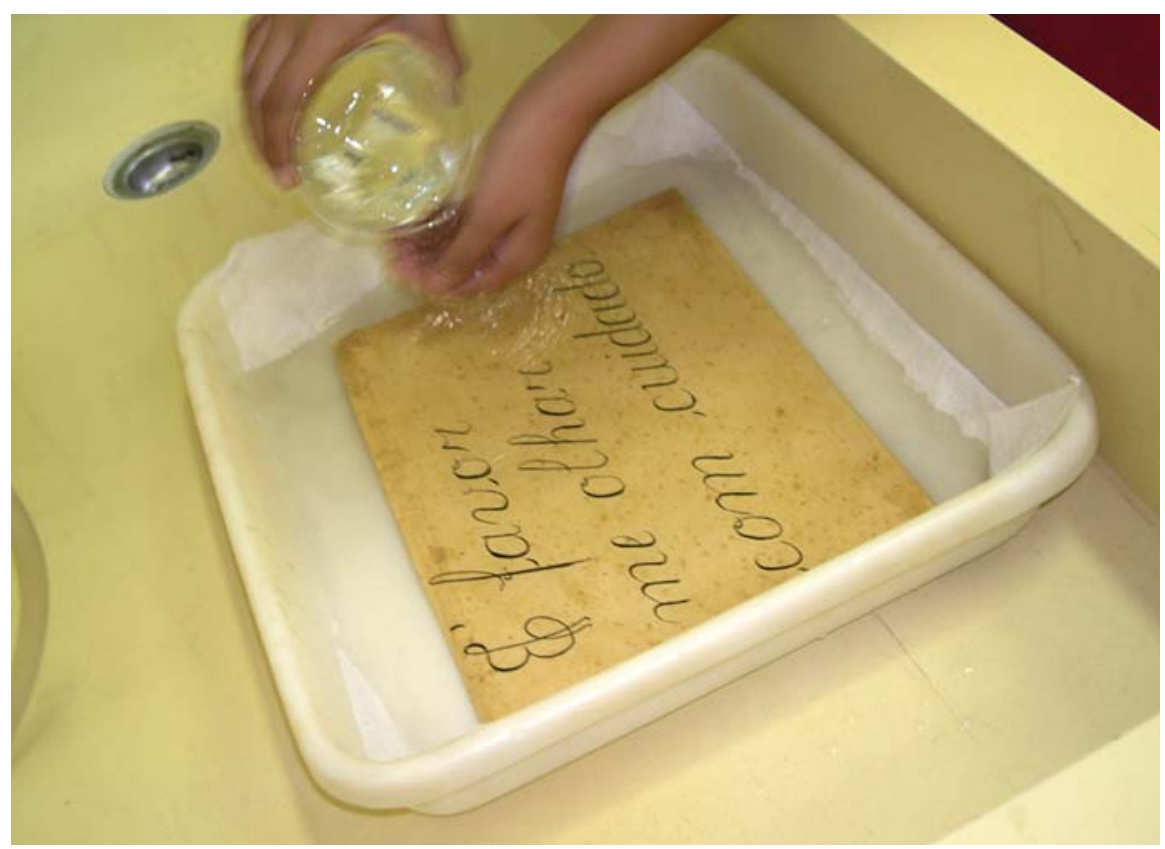

Figura 6 - Tratamento químico em folha de papel da contracapa. Acervo do Museu da Imagem e do Som de Goiás, Goiânia. Fotografia de Richam Samir, 2005. 


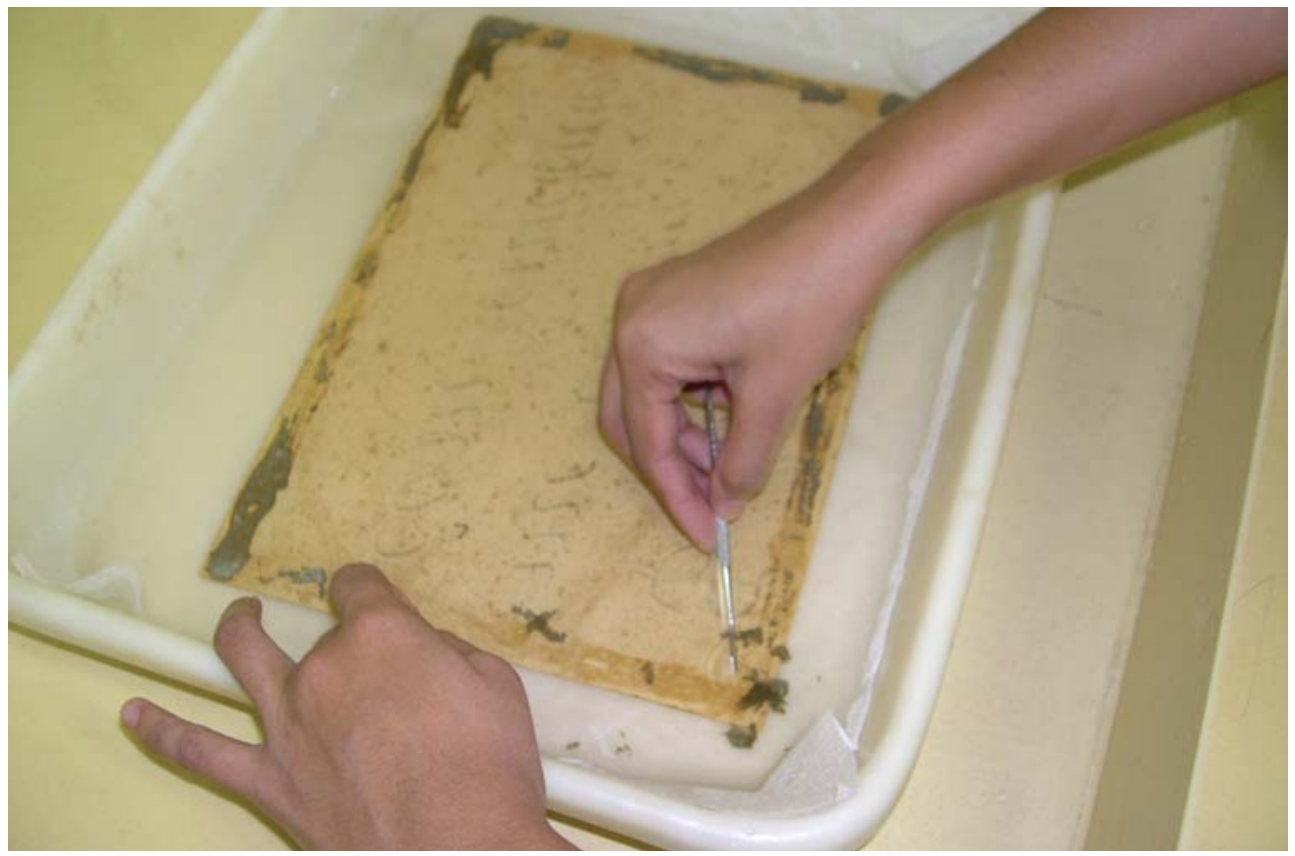

Figura 7 - Retirada de resíduos do verso da folha da contracapa. Acervo do Museu da Imagem e do Som de Goiás, Goiânia. Fotografia de Richam Samir, 2005.

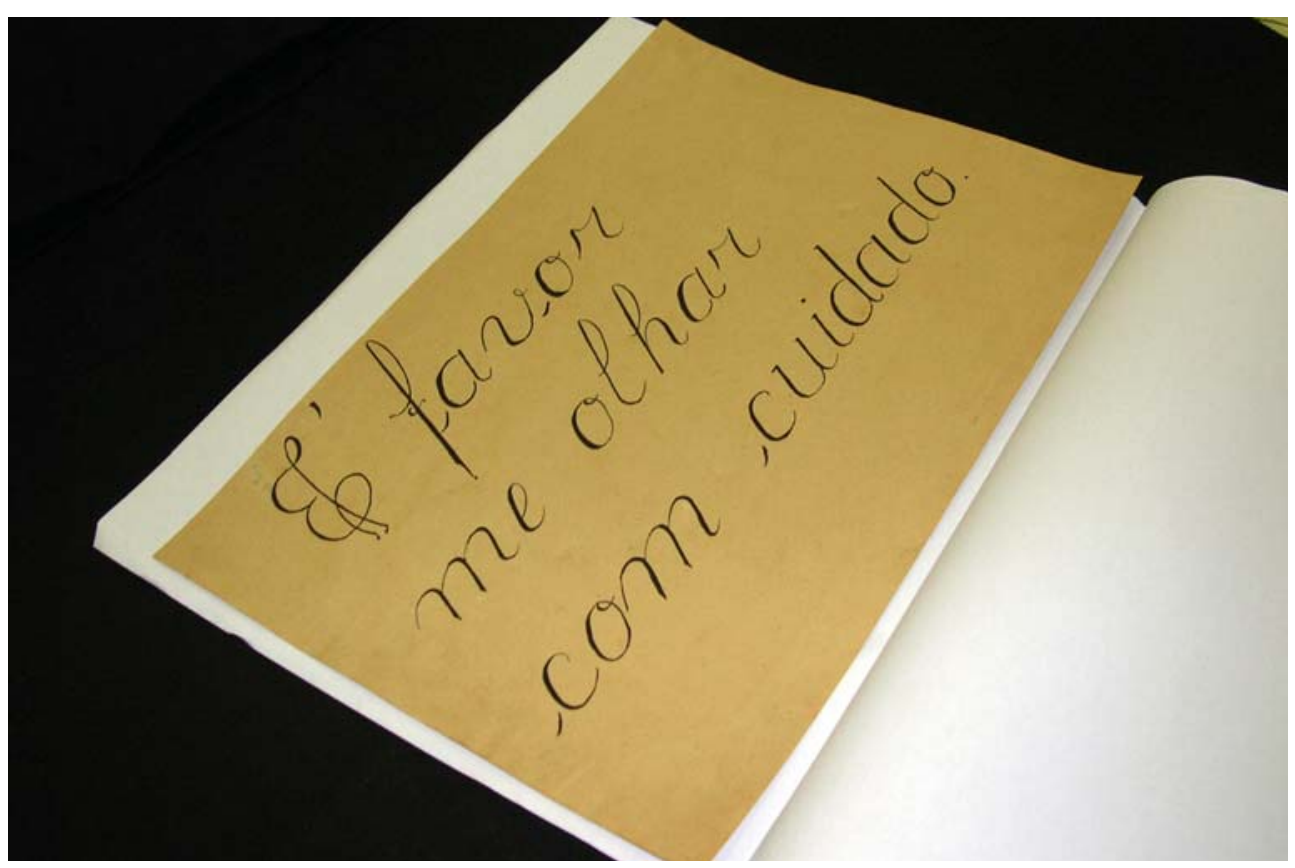

Figura 8 - A folha de papel da contracapa após o tratamento químico. Acervo do Museu da Imagem e do Som de Goiás, Goiânia. Fotografia de Richam Samir, 2005. 
reposicionamento das fotografias no novo suporte foi realizado de forma a manter o mesmo sistema anteriormente utilizado: adesão pelo verso. A opção foi pela fita adesiva GUDY ${ }^{\circledR}$ 870, que, além de apresentar boa estabilidade e reversibilidade, não promove o aparecimento de relevo. Finalmente, o álbum foi acondicionado em caixa porta-fólio revestida em material sintético (Figura 9).

Álbuns da Coleção Museu Estadual Prof. Zoroastro Artiaga-MZA

Os dois álbuns descritos a seguir integram a Coleção MZA, que foi encaminhada ao MIS-GO em 1999 sob a forma de Depósito. Além de álbuns fotográficos, essa coleção compreende fotografias lem preto e branco e em cores), cartões postais, diapositivos e discos compactos.

\section{Álbum do Interior Goiano}

álbum foi montado, provavelmente na década de 1950, por funcionários do Museu Estadual de Goiás ${ }^{11}$, com a preocupação de organizar e preservar as fotografias. Muitas fotos apresentam no verso um carimbo com a

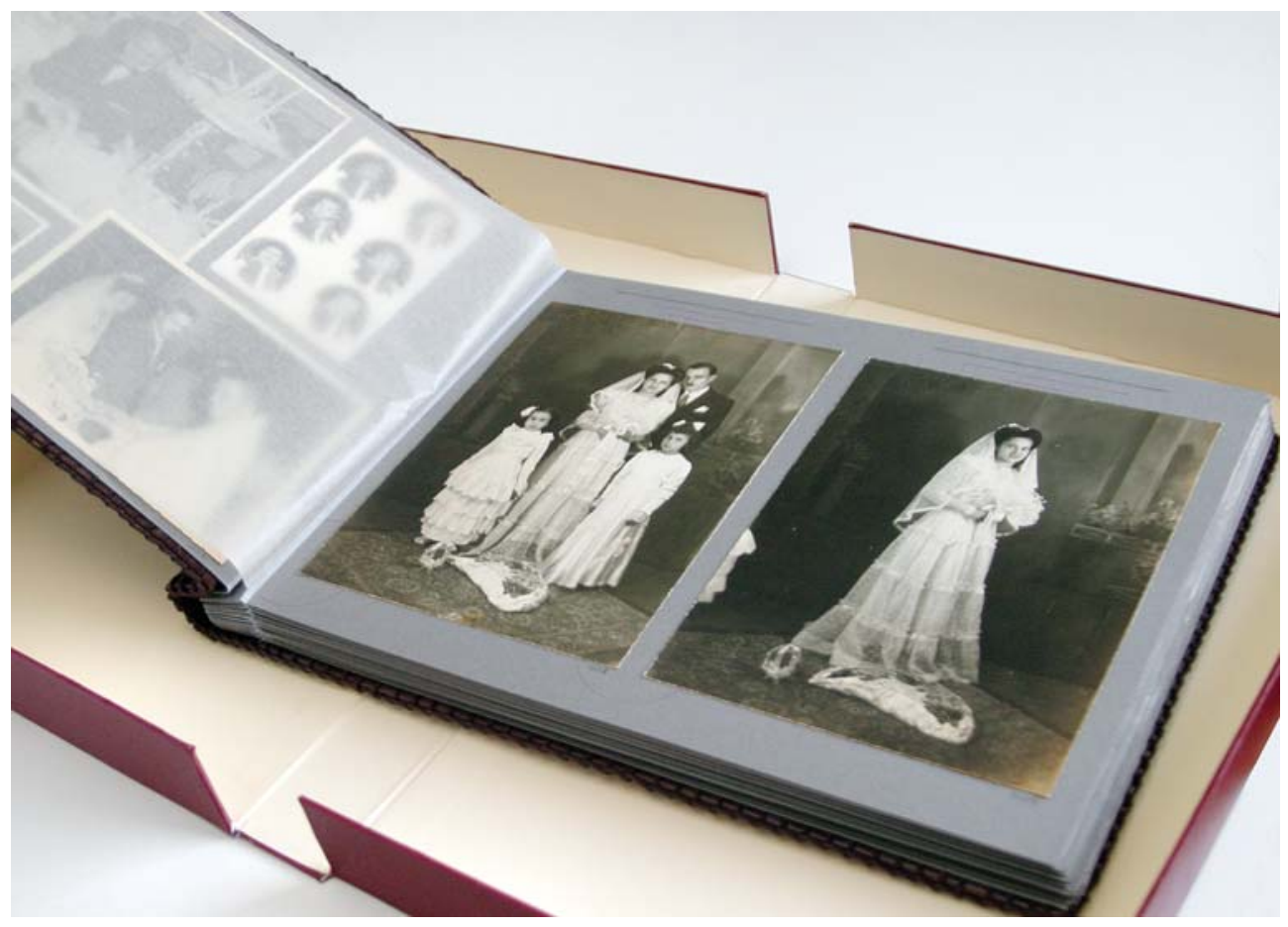

Figura 9 - Acondicionamento final do álbum da Coleção Luiz Pucci em caixa porta-fólio. Acervo do Museu da Imagem e do Som de Goiás, Goiânia. Fotografia de Paulo Rezende, 2006.
11. O Museu Estadual de Goiás foi criado pelo Decreto-Lei $\mathrm{n}^{\mathrm{o}} 383$, de 6 de fevereiro de 1946; em 16 de maio de 1965 , teve o nome alterado para Museu Goiano Prof. Zoroastro Artiaga (Lei $\mathrm{n}^{\circ}$ 5770), em homenagem ao primeiro diretor, que permaneceu no cargo até 1957 e, posteriormente, de 1965 a 1971; em 20 de agosto de 1980, sofreu nova alteração em seu nome, pelo DecretoLei $\mathrm{n}^{\circ} \mathbf{1 7 8 8}$, passando a ser denominado Museu Estadual Prof. Zoroastro Artiaga. 
seguinte inscrição: "Museu Estadual de Goiás.... Secção:.... Goiânia:.../.../..."; e, no espaço reservado para a data, a inscrição feita à caneta "07/1957", confirmando a preocupação em identificar as fotos pertencentes aquele museu. São fotografias que registram o surgimento e o desenvolvimento das principais cidades goianas, entre elas Anápolis, Caldas Novas, Rio Verde, Pirenópolis, Catalão, além de cidades que hoje pertencem ao estado do Tocantins, como Porto Nacional, Natividade, entre outras. Imagens de abertura de estradas, habitações na zona rural, produções agrícolas e pequenas fábricas de calçados misturavam-se com fotos de tipos humanos, edificações, fachadas residenciais, eventos sociopolíticos, culturais e datas comemorativas.

álbum não evidenciava uma classificação das fotografias, quer por município ou temática. Tampouco havia qualquer preocupação estética ou funcional na apresentação das imagens: as 470 fotos foram coladas no suporte de maneira a aproveitar ao máximo o espaço, a ponto de encontrarmos, na mesma página, fotografias orientadas horizontal e verticalmente, à revelia da orientação original dos enquadramentos. De tamanhos variados $19 \times 14 \mathrm{~cm}$, $12 \times 18 \mathrm{~cm}, 18 \times 24 \mathrm{~cm}$ e $20 \times 25 \mathrm{~cm}$ ), as fotografias estavam, em sua maioria, totalmente coladas no suporte, cujas folhas eram de papel cartão acinzentado e também de cartolina de cor azul-clara. As páginas encontravamse com manchas, excrementos de insetos e outras sujidades, além de dobras, rasgos e perdas nas bordas (Figura 10). As fotos estavam em avançado estado

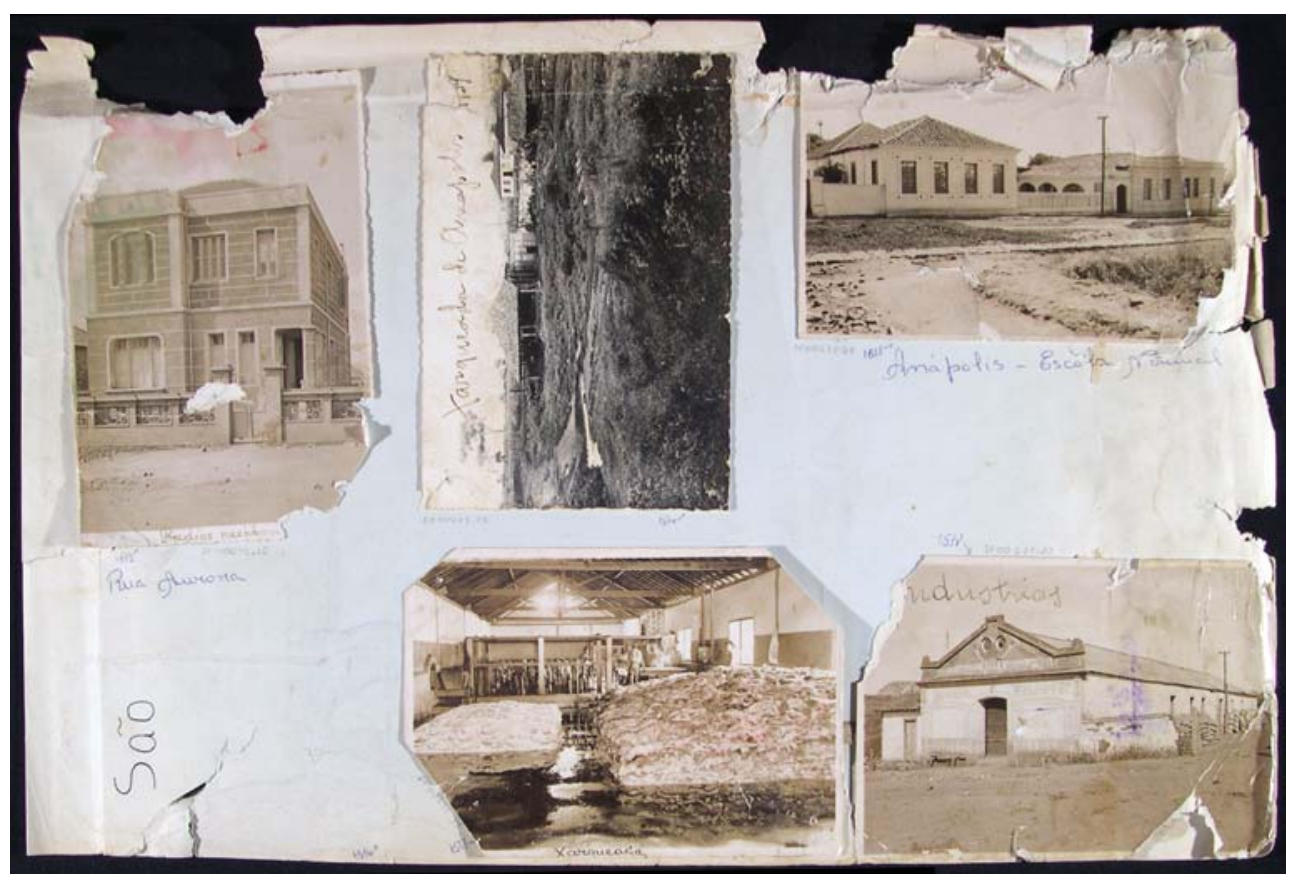

Figura 10 - As fotografias e o suporte do Álbum do Interior Goiano, em avançado estágio de deterioração. Acervo do Museu da Imagem e do Som de Goiás, Goiânia. Fotografia de Richam Samir, 2005. 
de deterioração, provocado, principalmente, por manipulação e ambiente de guarda impróprios. Observava-se, em muitas delas, perfurações, rasgos, perda da emulsão, partes faltantes, resíduos de papel e cola, manchas e outras sujidades (Figura 11). Algumas apresentavam inscrições descritivas, feitas a caneta sobre a imagem. $\bigcirc$ conjunto, constituído de 58 páginas, não tinha capa e, por tais dimensões, estava acondicionado em duas caixas de papel cartão.

Levando-se em conta o estado geral de conservação do álbum e as características de apresentação das fotografias antes descritas, as conservadoras decidiram pela remoção das fotos do suporte deteriorado, permitindo um complexo tratamento de conservação em cada uma delas. $\bigcirc$ procedimento foi realizado mecanicamente, com auxílio de uma espátula de bambu. Confirmouse, após a retirada, a suposição de que as fotos estavam coladas ao suporte com adesivo à base de PVA (poliacetato de vinila), de difícil remoção. Também se observou a presença de goma arábica e resíduos de papel de suportes anteriores, indicando que o estágio avançado de deterioração das fotografias tenha sido decorrente de sucessivas manipulações inadequadas.

A remoção dos resíduos de PVA exigia um solvente capaz de solubilizar o adesivo sem comprometer os demais componentes da fotografia. Após uma série de tentativas para encontrar a dosagem dos componentes do solvente, decidiu-se pela utilização de uma solução de acetona e álcool etílico, na proporção de $3: 1$. A aplicação dessa solução dava-se após a completa remoção

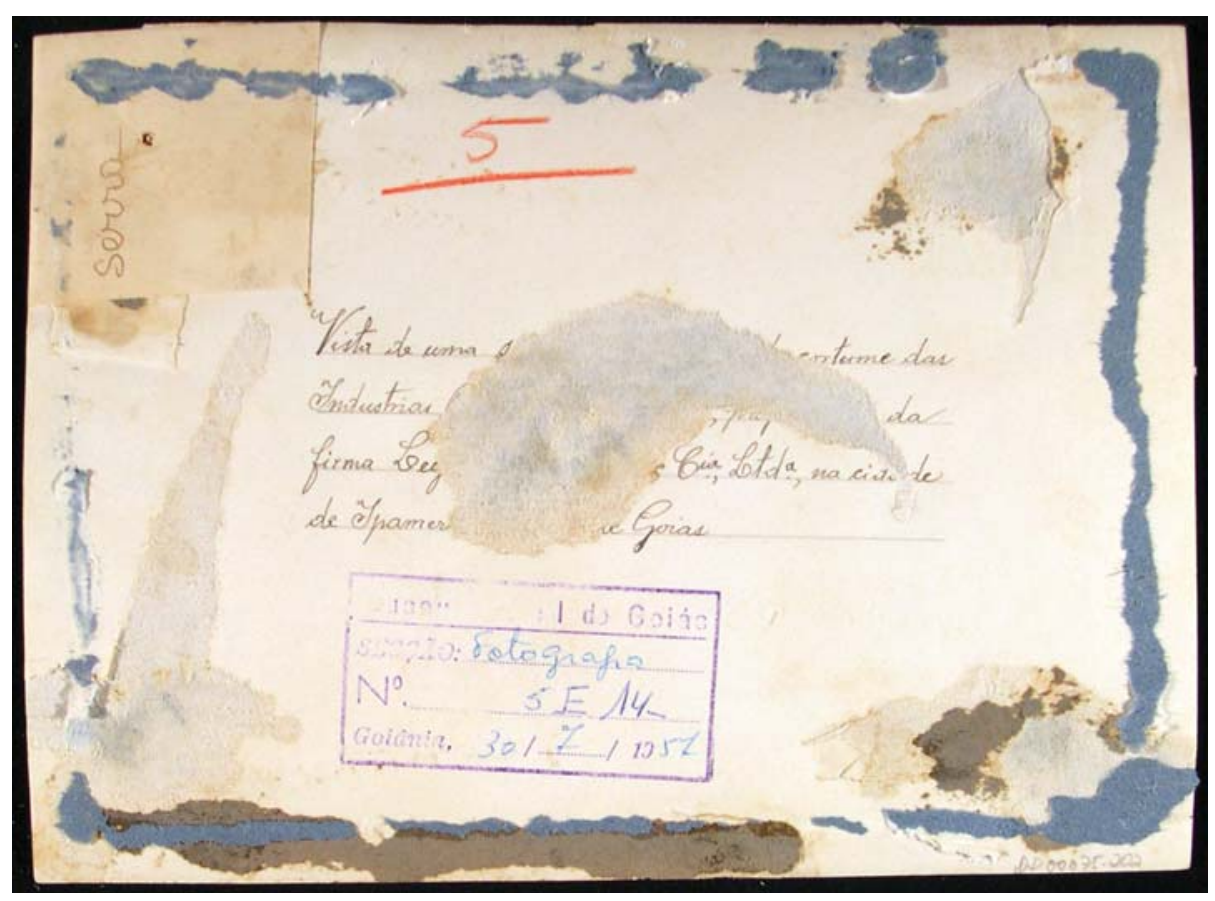

Figura 11 - Verso de uma fotografia com resíduos de papel e cola, inscrições a caneta e a lápis e enxertos feitos anteriormente. Acervo do Museu da Imagem e do Som de Goiás, Goiânia. Fotografia de Richam Samir, 2005. 
de resíduos de suportes anteriores, pois alguns dos papéis apresentavam corantes cuja solubilidade poderia resultar em manchas no papel fotográfico. A goma arábica, também encontrada no verso das fotografias, foi removida com a aplicação de umidade controlada, com metilcelulose a $6 \%$ em água.

O passo seguinte foi a estabilização das fotografias com danos estruturais. Rasgos, vincos e delaminações foram consolidados com a utilização de papel japonês e metilcelulose (Figura 12). As perdas de suporte foram compensadas com enxertos de papel artesanal, de gramatura e cor compatíveis com o original (Figuras 13 e 14). Nos casos em que a perda comprometia a leitura da imagem, foi feita a reintegração visual com aquarela, sem a pretensão de completar as imagens, mas para melhor apresentação estética. As fotografias mais frágeis passaram pelo tratamento de laminação laderência da fotografia danificada a um novo suporte), realizada com papel japonês de baixa gramatura, de forma a permitir a leitura das informações contidas no verso das imagens (Figura 15).

A forma de acondicionamento escolhida após o tratamento foi o álbum tipo porta-fólio com bolsas de poliéster. As fotografias foram colocadas em dois álbuns, respeitando a forma original de apresentação do conjunto; cada um dos volumes foi acondicionado em caixa rígida, tipo luva (Figura 16).

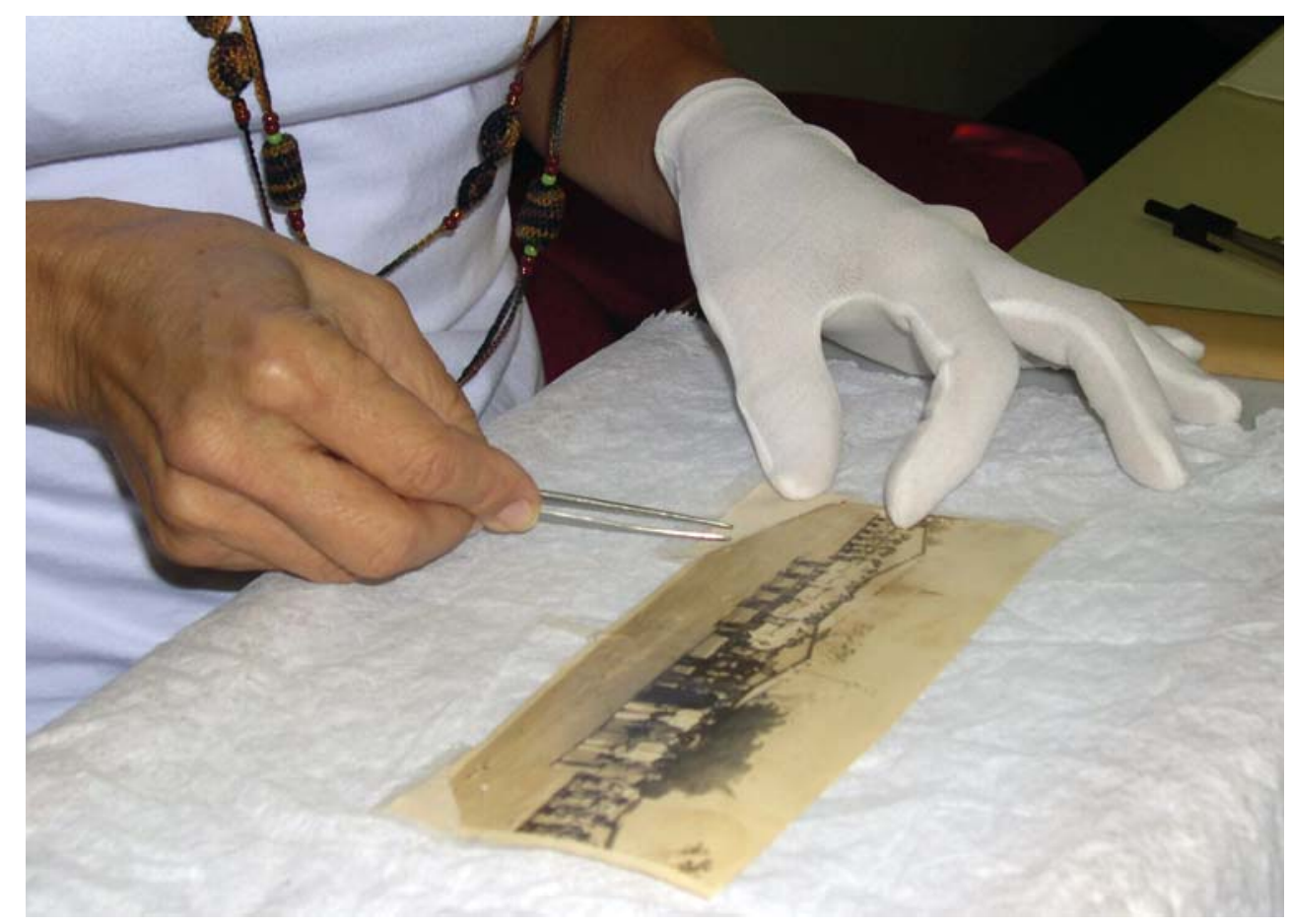

Figura 12 - Conservadora aplica técnica de enxerto em uma fotografia. Acervo do Museu da Imagem e do Som de Goiás, Goiânia. Fotografia de Richam Samir, 2005. 


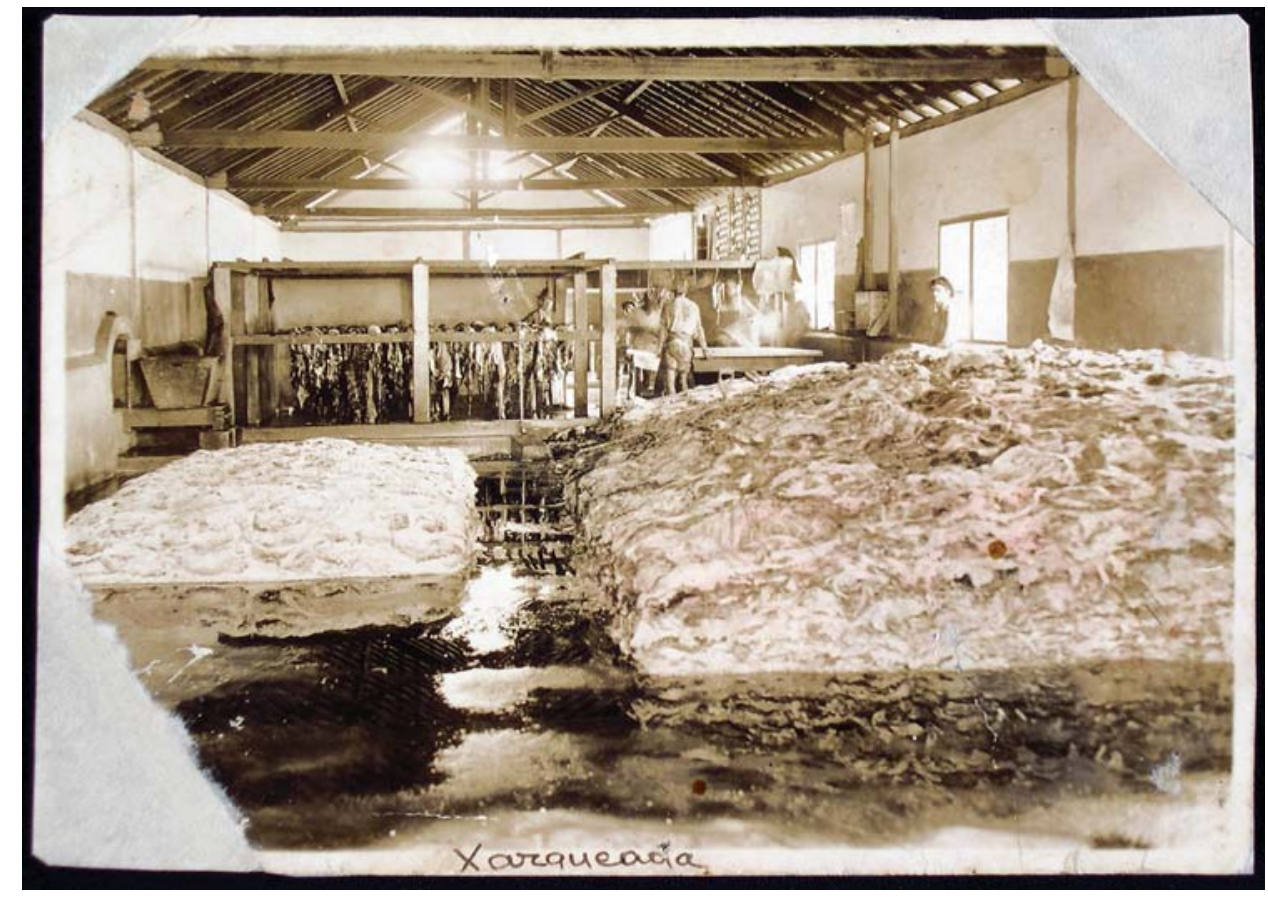

Figura 13 - Fotografia do Álbum do Interior Goiano, após o tratamento de conservação. Acervo do Museu da Imagem e do Som de Goiás, Goiânia. Reprodução de Richam Samir, 2005.

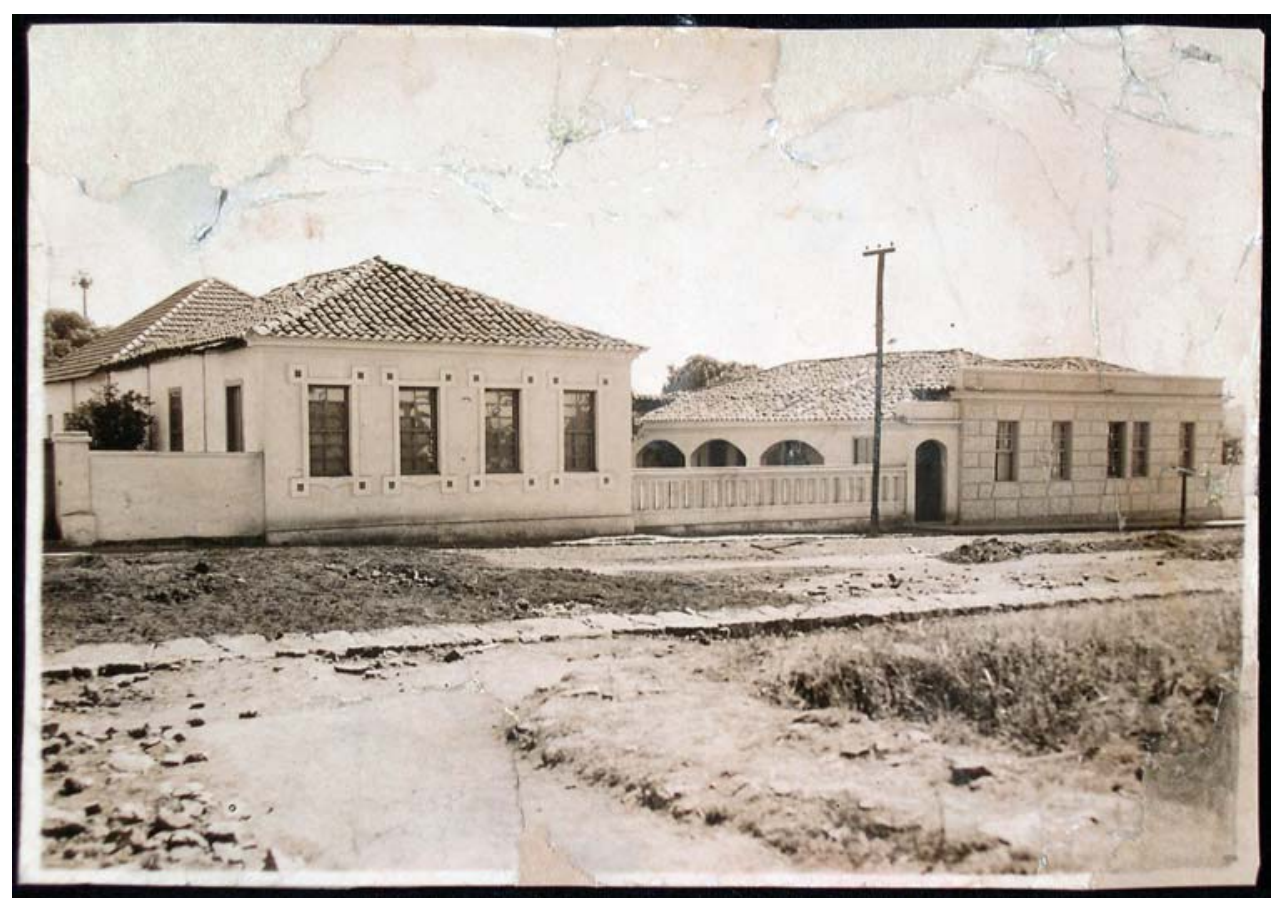

Figura 14 - Fotografia do Álbum do Interior Goiano, após laminação e enxerto. Acervo do Museu da Imagem e do Som de Goiás, Goiânia. Reprodução de Richam Samir, 2005. 


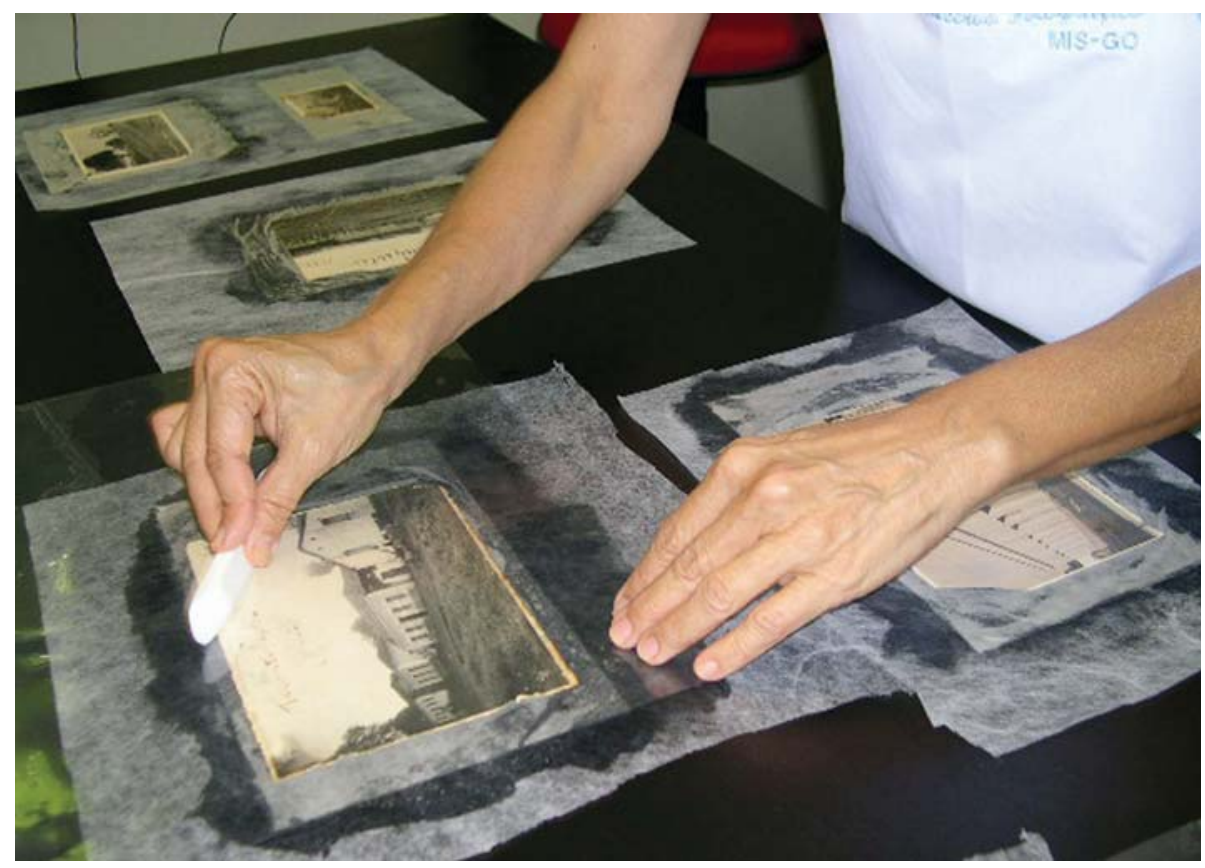

Figura 15 - Conservadora aplica técnica de laminação em fotografias do Álbum do Interior Goiano. Acervo do Museu da Imagem e do Som de Goiás, Goiânia. Fotografia de Richam Samir, 2005.

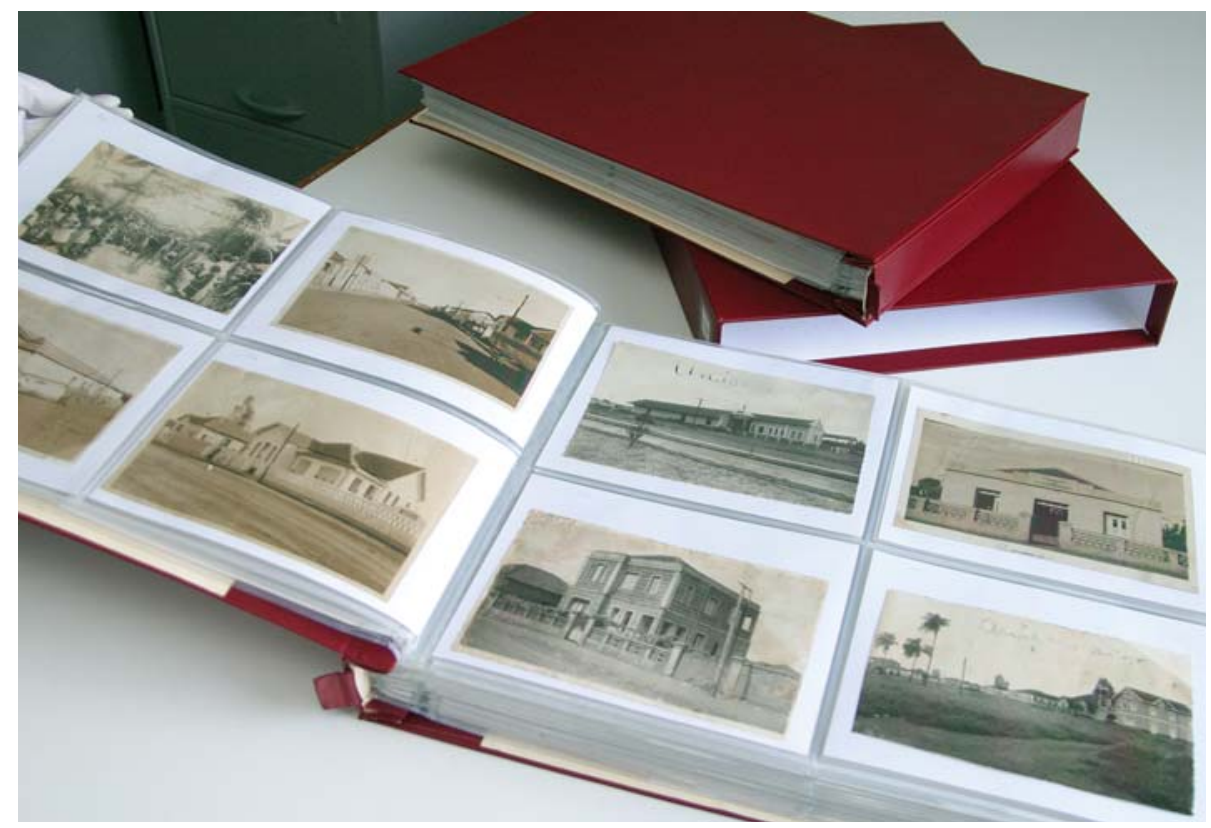

Figura 16 - As fotografias em novo suporte: álbum porta-fólio e caixa tipo luva. Acervo do Museu da Imagem e do Som de Goiás, Goiânia. Fotografia de Paulo Rezende, 2006. 
As fotografias do álbum documentam o Décimo Circuito de Goiânia, competição esportiva realizada em 24 de outubro de 1944, na comemoração do aniversário de Goiânia. O conjunto de imagens do fotógrafo pioneiro Sílvio Berto registra corridas de bicicletas e motos. São 20 fotografias e informações textuais, agrupadas em 13 tabelas, com os nomes dos atletas participantes, as modalidades disputadas, a definição do percurso e as classificações nas diversas provas realizadas. As primeiras páginas, na dimensão de $32,5 \times 22 \mathrm{~cm}$, trazem fotografias com legendas descritivas a tinta, ao lado direito de cada imagem (Figura 17). As demais páginas contêm 9 tabelas datilografadas no formato $32,5 \times 22 \mathrm{~cm}$, e 4 no formato de $32,5 \times 44 \mathrm{~cm}$, sendo que estas se encontravam dobradas ao meio. As fotos eram fixadas com grampos de metal e apresentavamse amarelecidas, com sinais de ferrugem e outras sujidades. Todas as páginas em papel tipo jornal, de baixa gramatura, estavam amarelecidas, amassadas e com rasgos nas extremidades dos vincos (Figura 18).

As intervenções realizadas neste álbum envolveram técnicas de higienização e estabilização das fotografias, e o resgate estrutural de todas as suas páginas. As fotografias passaram por higienização mecânica e obturação dos furos deixados pelos grampos metálicos. As folhas contendo fotos e as informações textuais foram higienizadas e os reparos nas áreas de rasgos e

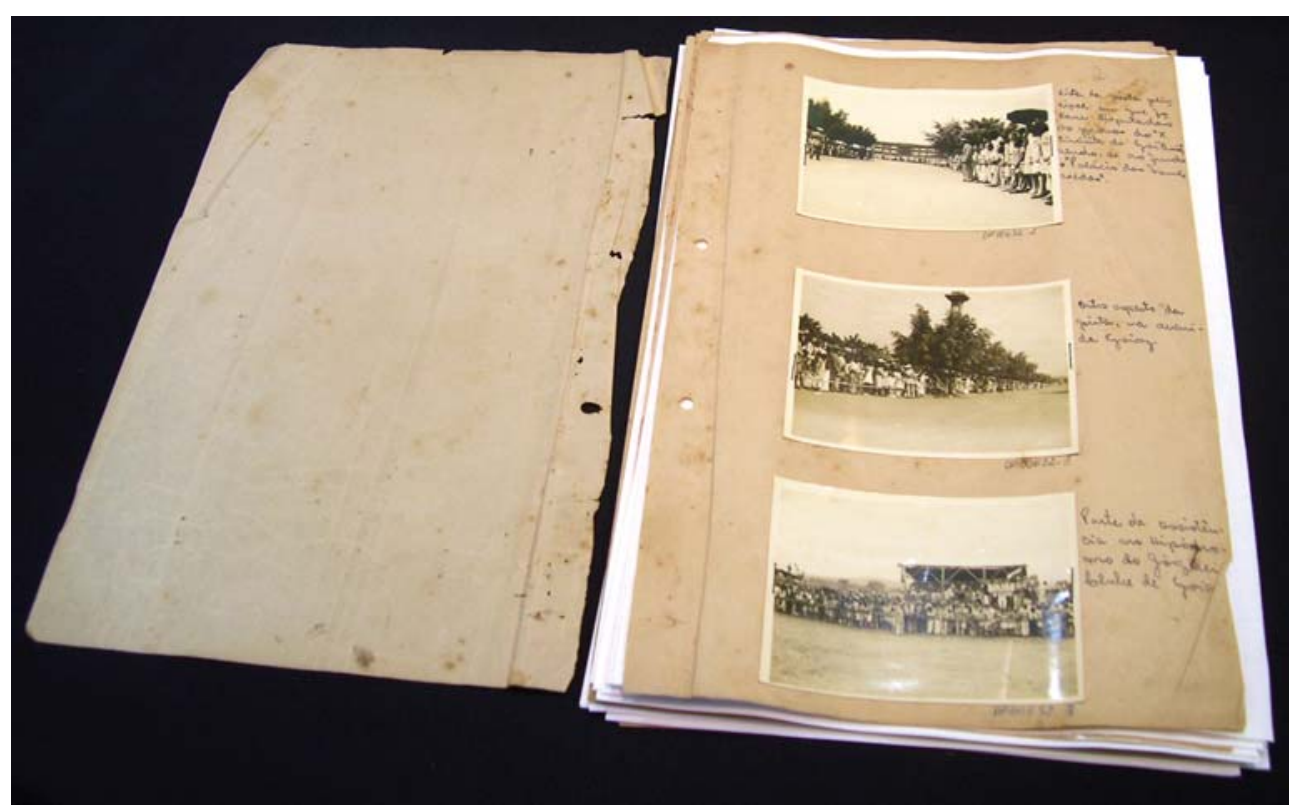

Figura 17 - Álbum do Décimo Circuito de Goiânia, no estado de conservação anterior ao tratamento. Acervo do Museu da Imagem e do Som de Goiás, Goiânia. Fotografia de Richam Samir, 2005 
12.Acary de Passos Oliveira, sertanista que participou da expedição Roncador -Xingu durante o Estado Novo, coletando material etnográfico sobre várias tribos brasileiras: Kamayurá, Bororo, Txicão, Javaé, Xavante, Krahó, Apinayé entre outras. Acumulou farto.

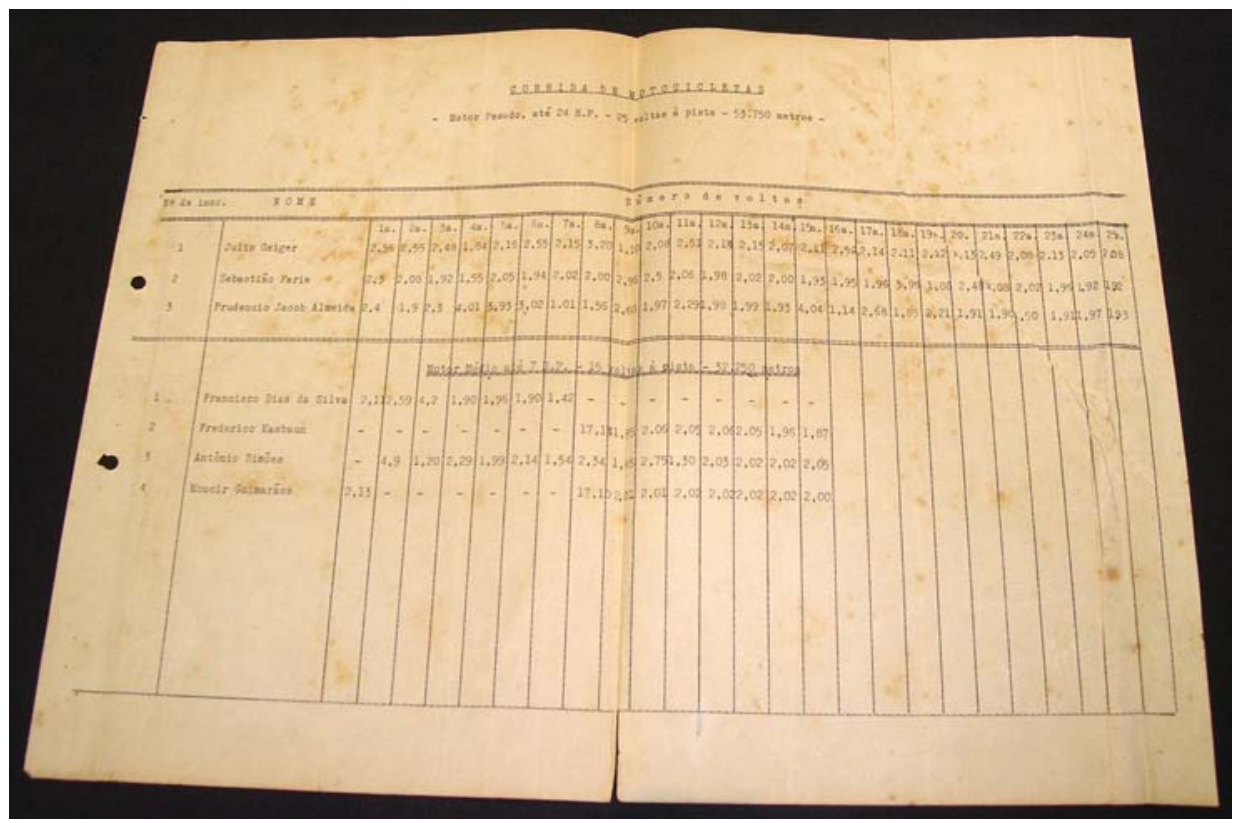

Figura 18 - Exemplo de página com informações textuais, em papel tipo jornal, amarelecida, amassada e com rasgos. Acervo do Museu da Imagem e do Som de Goiás, Goiânia. Fotografia de Richam Samir, 2005.

vincos foram feitos com fita Filmoplast ${ }^{\circledR}$ P, ativada por calor (Figura 19). Foi utilizada esta fita porque o papel - tipo jornal - não responderia satisfatoriamente a um tratamento envolvendo umidade. Após a realização dos reparos, todas as folhas foram planificadas e a montagem das fotografias ao suporte tratado foi feita com o adesivo GUDY® 870. $\bigcirc$ acondicionamento final do álbum foi planejado para que o mesmo mantivesse aparência e estrutura parecidas com o original e as tabelas não voltassem a ser dobradas. $\bigcirc$ álbum foi acondicionado em jaquetas de poliéster, presas por parafusos, pela lateral esquerda, em lombada de cartão recoberto por material sintético. As tabelas foram acondicionadas individualmente, abertas, em jaquetas de poliéster com suporte de cartão neutro. Foi produzida uma única caixa, tipo porta-fólio e revestida em material sintético, para acondicionar o álbum e as tabelas conjuntamente. $\bigcirc$ álbum ficou ao fundo e, sobre este, as tabelas, apoiadas pelas bordas por um suporte que envolve o álbum. Tal suporte tem a mesma altura do álbum e completa a área da caixa, pois o álbum tem dimensões menores que as das planilhas (Figura 20).

Álbuns da Coleção José Mendonça Teles

Os dois álbuns foram organizados pelo sertanista Acary de Passos Oliveira (17.2.1907 - 23.5.1993)12 e encaminhados, logo após sua morte, 


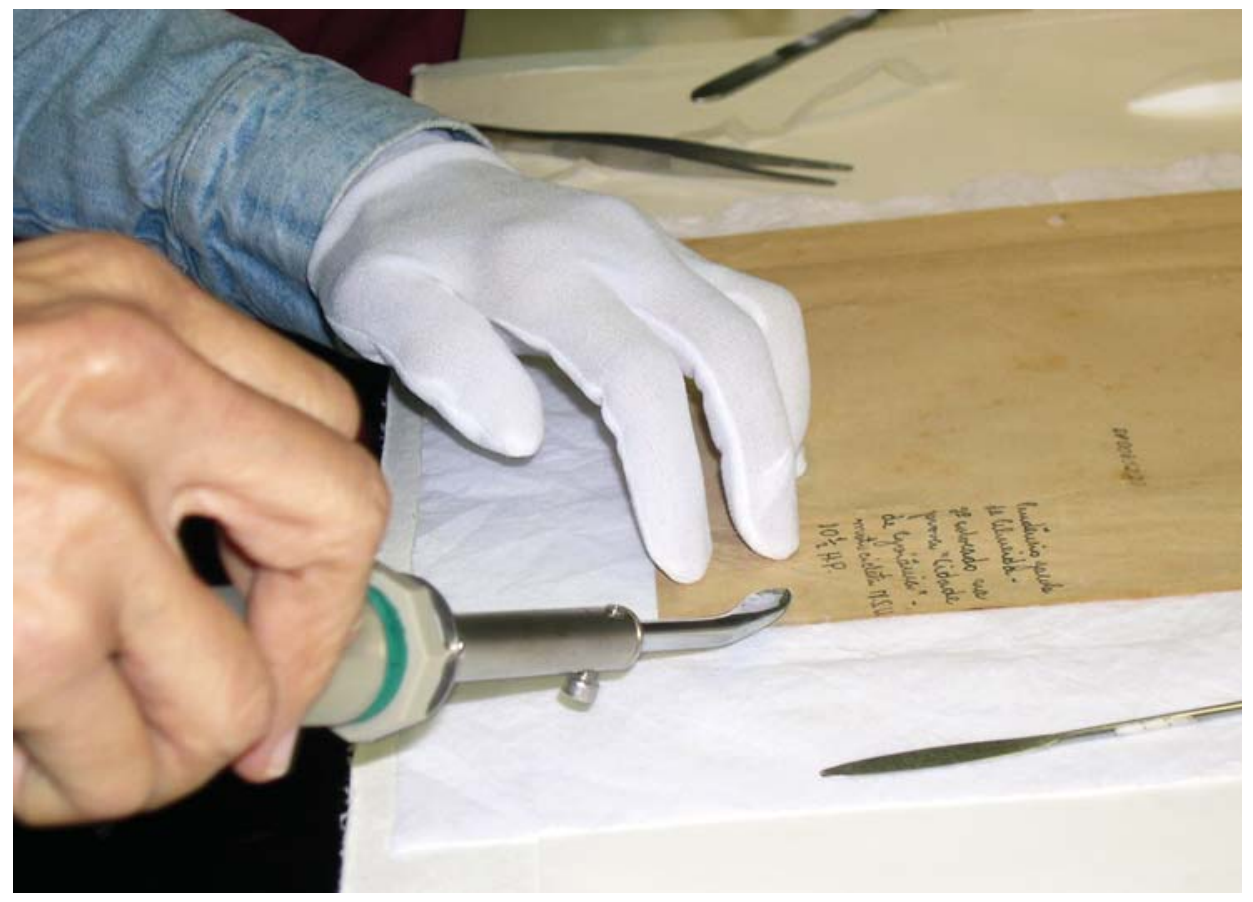

Figura 19 - Conservadora faz reparos em páginas do állbum com fita Filmoplast P. Fotografia de Richam Samir, 2005.

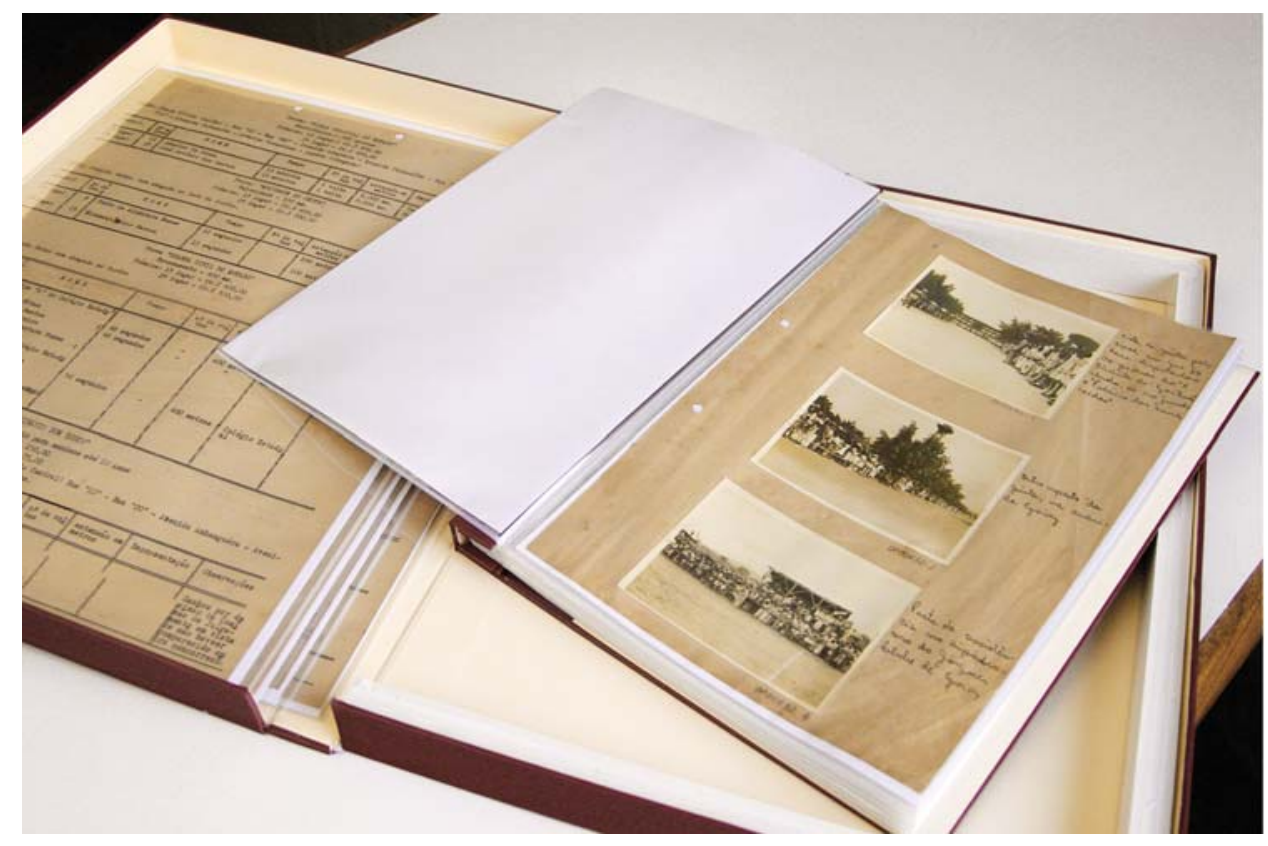

Figura 20 - $\bigcirc$ acondicionamento final do Álbum do Décimo Circuito de Goiânia: as tabelas abertas e o volume com as fotografias em única caixa tipo porta-fólio. Foto de Paulo Rezende, 2006. 
ao escritor goiano José Mendonça Teles, que os doou ao MIS-GO em 2001. Os álbuns hoje fazem parte da Coleção José Mendonça Teles.

\section{Álbum I (série Acary de Passos Oliveira)}

As fotografias do álbum registram uma expedição realizada c. 1937, acompanhando o rio das Mortes e no rio Araguaia, entre os estados de Goiás e Mato Grosso, pela Missão Salesiana sob a responsabilidade do Padre Hipólito Chovelon. As missões salesianas tentaram, durante as décadas de 1930 e 1940, a pacificação de índios na região. As imagens apresentam a derrubada de roças, a construção dos primeiros ranchos e algumas embarcações no rio. Outro importante conjunto de fotografias registra a viagem feita pelo presidente Getúlio Vargas à aldeia dos índios Karajá na llha do Bananal, em agosto de 1940. As fotografias ilustram o contato da comitiva presidencial com os índios, o acampamento e as belezas naturais da região.

álbum não tinha capa, e as páginas eram de papel de baixa qualidade, unidas por um prendedor de metal com sinais de oxidação. $O$ suporte inadequado e, provavelmente, o ambiente de guarda, quente e seco, provocaram o abaulamento das 77 fotografias que integram o conjunto (Figura 21 1). Além disso, as imagens mostravam-se amarelecidas e com sujidades.

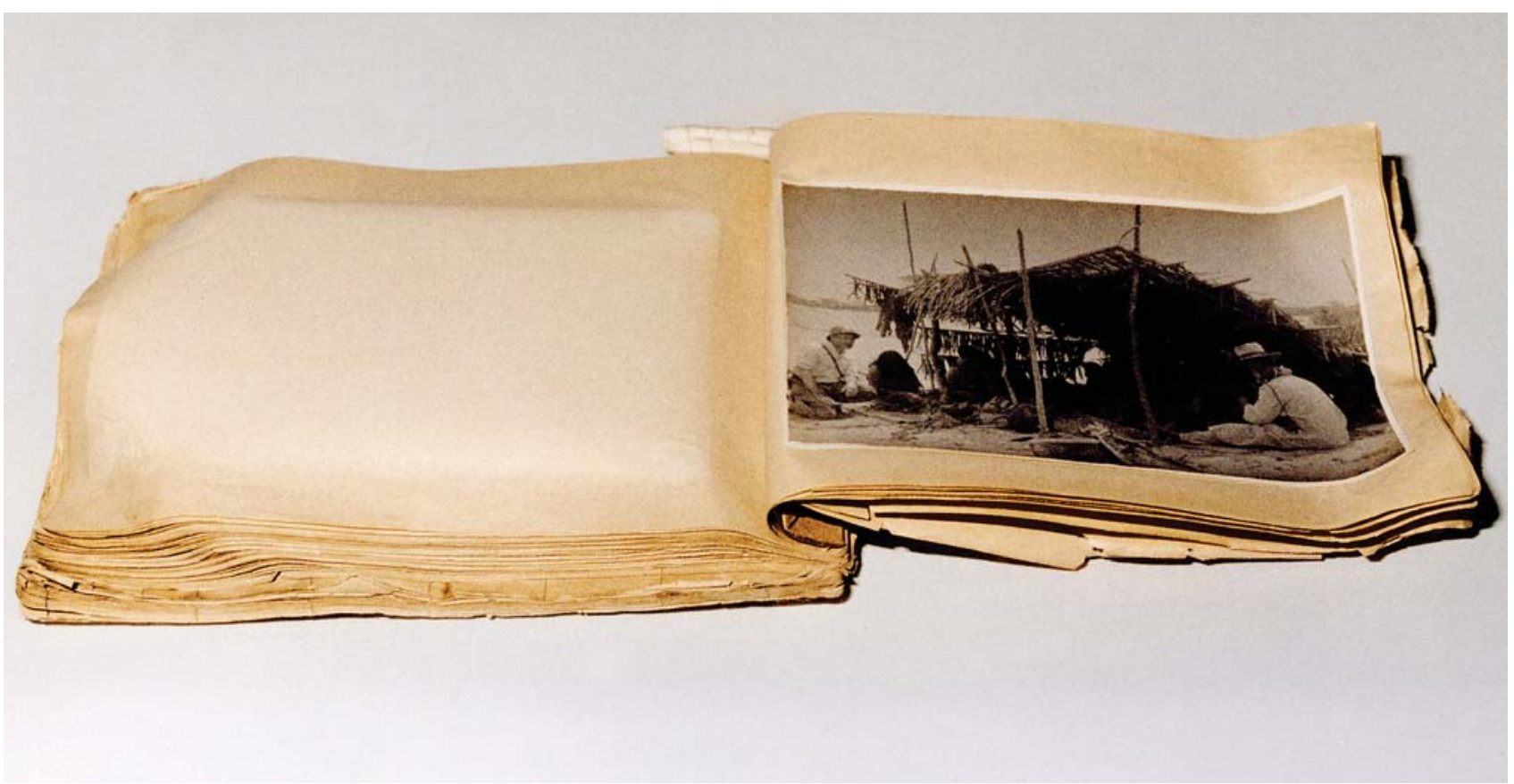

Figura 21 - Apresentação original do Álbum I da Coleção José Mendonça Teles, evidenciando o volume completamente abaulado. Fotografia de Richam Samir, 2005. 
Álbum II (série Acary de Passos Oliveira)

$\bigcirc$ álbum foi organizado com 67 fotografias, em sua maioria dos fotógrafos pioneiros Eduardo Bilemiian e Antônio Pereira da Silva, que registram aspectos físicos, sociais e urbanísticos do período da construção de Goiânia e, ainda, eventos realizados em Uberaba (MG) e na cidade do Rio de Janeiro (DF). As fotografias têm dimensões variadas $16 \times 6 \mathrm{~cm}, 6 \times 9 \mathrm{~cm}, 9 \times 14 \mathrm{~cm}, 12 \times$ $18 \mathrm{~cm} \mathrm{e} 18 \times 24 \mathrm{~cm})$. Podemos destacar, do conjunto de imagens, a visita a Goiânia de Willy Aureli, chefe da Bandeira Piratininga, em 1936, e a visita do Presidente Vargas, em agosto de 1940. Também integram o conjunto imagens representativas do pavilhão de Goiás, na Feira Internacional de Amostras do Rio de Janeiro, e do Presidente Vargas, na inauguração de uma feira agropecuária em Uberaba.

A capa do álbum, de papel tipo cartão, estava muito deteriorada e com as bordas rasgadas. As páginas centrais eram de papel de qualidade inferior e baixa gramatura; algumas, em papel seda, apresentavam-se amarelecidas, rasgadas e quebradiças, além de unidas por um prendedor de metal (Figura 22). Apesar do acondicionamento inadequado, as fotografias não

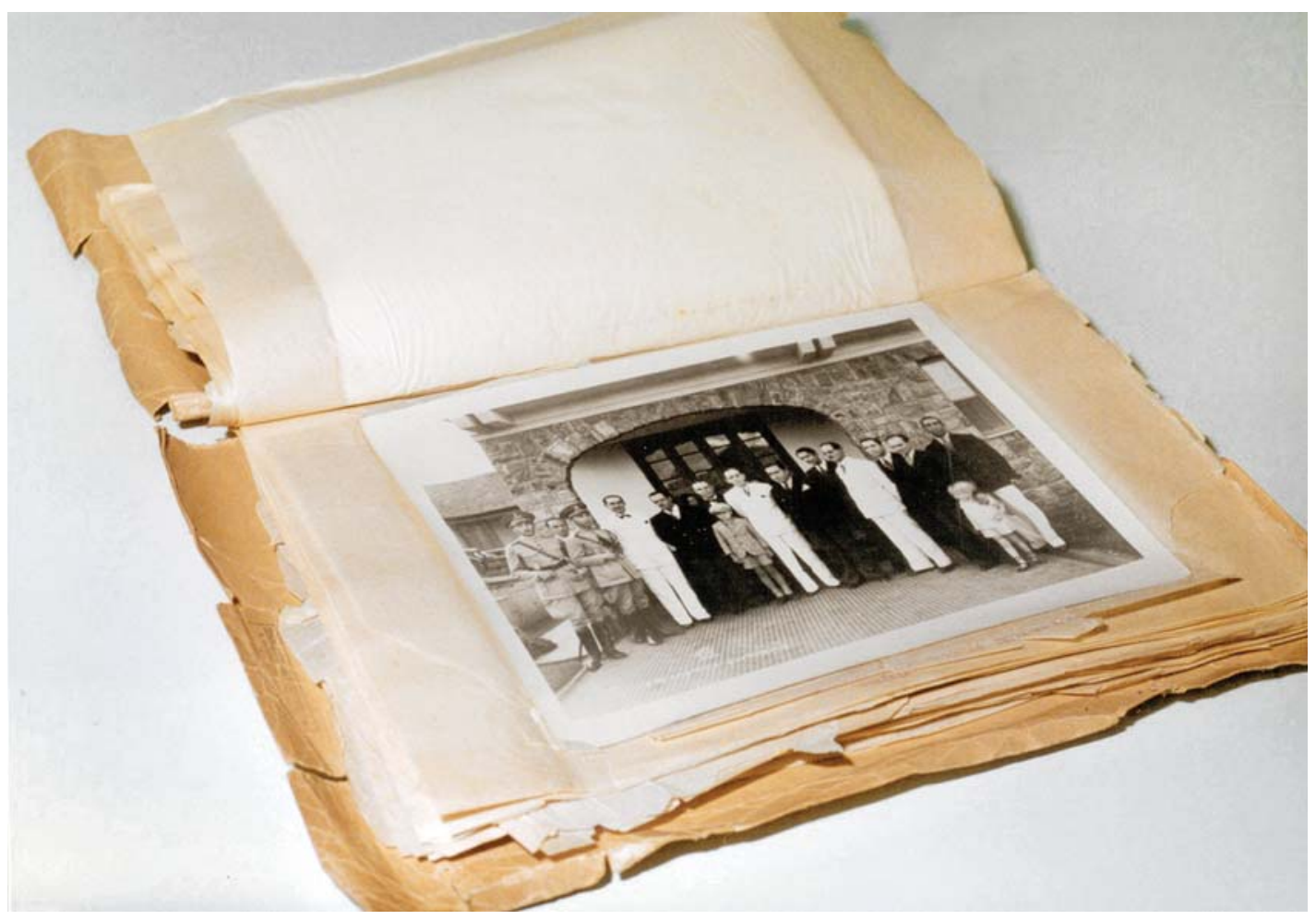

Figura 22 - Suporte do Álbum II da Coleção José Mendonça Teles, em condições precárias. Fotografia de Richam Samir, 2005. 
apresentavam problemas de deterioração, apenas a ocorrência de manchas e sujidades.

As fotografias dos álbuns I e II da Coleção José Mendonça Teles, após terem sido removidas dos suportes originais deteriorados, foram submetidas a técnicas de higienização mecânica e química e, no caso do álbum l, a procedimento de planificação. Em seguida, foram colocadas em álbuns porta-fólio, com duas e quatro bolsas de poliéster, obedecendo-se a mesma ordem de apresentação original. Caixas rígidas tipo luva complementaram o acondicionamento (Figura 23).

Reprodução fotográfica

A reprodução fotográfica complementou o tratamento de conservação, possibilitando a produção de negativos de segunda geração para realizar, por seu intermédio, ampliações positivas, preservando os originais e viabilizando a digitalização. O trabalho foi realizado por Richam Samir, fotógrafo do CCPF. Em função do contraste e do estado de conservação das fotos definiram-se três

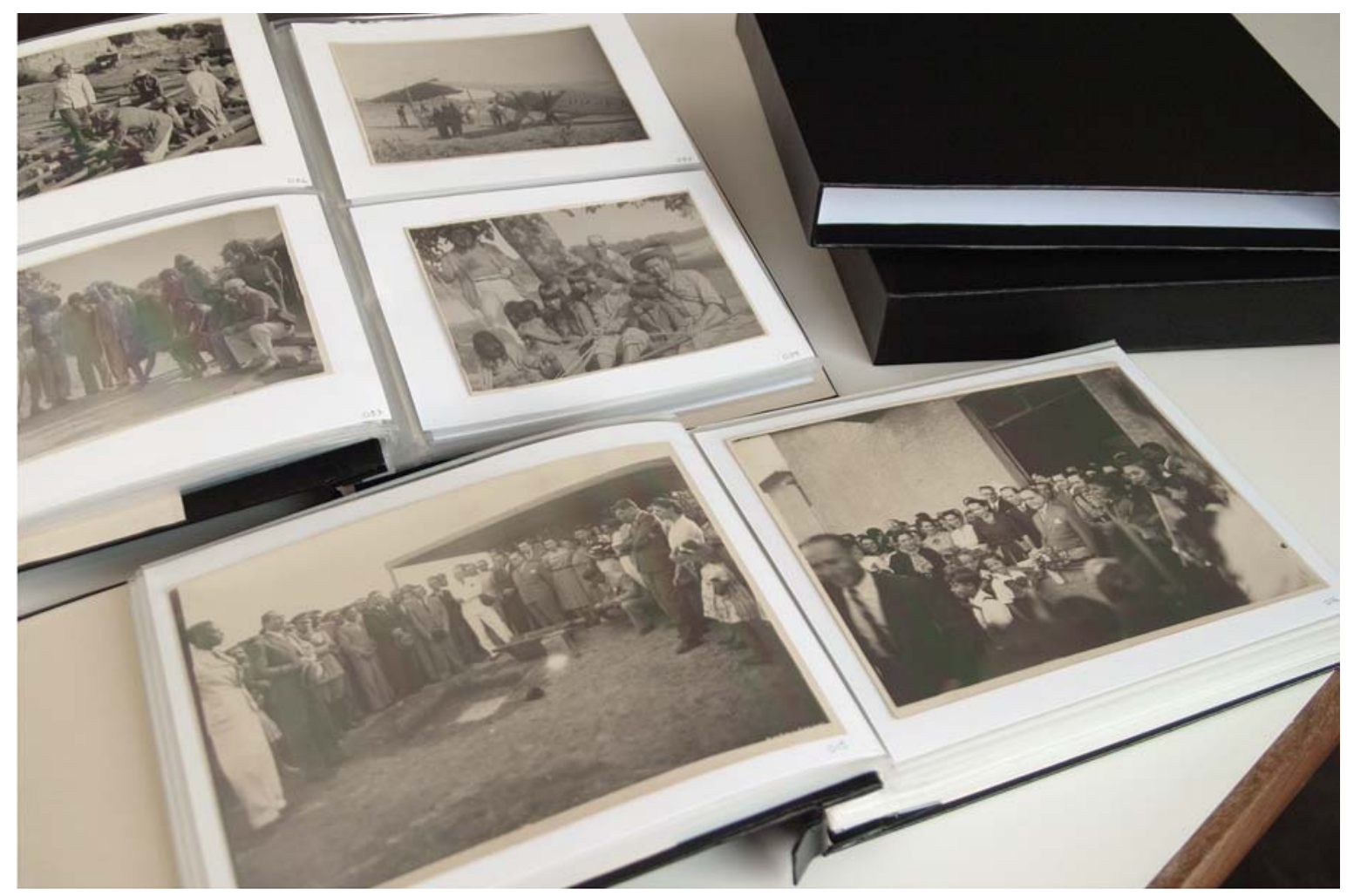

Figura 23 - As fotografias dos Álbuns I e || acondicionadas em novos suportes, após o tratamento de conservação. Fotografia de Paulo Rezende, 2006. 
grupos distintos de documentos, que orientaram os procedimentos técnicos no desenvolvimento da reprodução fotográfica: imagens com contraste normal e que não necessitavam de tratamento diferenciado durante a reprodução e no processamento laboratorial; imagens com pouco contraste ou esmaecidas, que foram reproduzidas com a utilização de filtro azul para aumentar o contraste; imagens coloridas "à mão", que foram reproduzidas com filme colorido, para manter suas características. Os filmes utilizados foram o Kodak T MAX 100/120 e o Fuji REALA 100/120, que geraram fotogramas no tamanho $6 \times 7 \mathrm{~cm}$. Todo o material produzido - filmes e papéis fotográficos - foi submetido a tratamento de permanência por meio da utilização de dois banhos fixadores: banho auxiliar à base de sulfito de sódio e viragem final de selênio. Esse procedimento é adotado com sucesso há muitos anos nos laboratórios do CCPF. Os filmes negativos foram acondicionados em cartelas de polietileno, envelopes alcalinos e caixas tipo fichário; as cópias-contato em álbuns portantes e caixas tipo luva.

Conclusão

tratamento de conservação realizado na coleção de álbuns do MIS-GO representou um desafio à equipe de conservadoras do CCPF e de técnicos do museu, não só pelo avançado estágio de deterioração em que se apresentavam os papéis suporte, entrefolhamentos e as fotografias, mas pelas deliberações em relação a medidas a serem adotadas durante o tratamento. Ainda que se tenha efetivado um grande número de procedimentos de conservação, não se pode afirmar que a ênfase do projeto decorra principalmente de operações técnicas bem sucedidas. Ressaltamos, anteriormente, a dificuldade da equipe em decisões importantes, como a de remover as fotografias e substituir o suporte original de quatro dos álbuns. A escolha dos novos acondicionamentos também foi muito discutida; decidiu-se pela manutenção de suportes com características de álbuns, que valorizassem tanto o conjunto quanto os documentos fotográficos individualmente. Particularmente no caso do Álbum do Interior Goiano, isso fica bastante evidenciado, pois a quantidade de fotos e sua disposição em cada uma das páginas não favoreciam a apreciação das imagens. Os álbuns remontados indicam que houve um aprimoramento, no que se refere às condições de arranjo nos conjuntos originais, já que a apresentação anterior ao tratamento (folhas soltas) não permitia sequer recuperar sua condição de artefato de visualização de imagens fotográficas. Além disso, a forma de acondicionamento escolhida proporcionou a valorização das fotografias individualmente. Seus atributos técnicos e estéticos foram realçados, seu conteúdo e suas informações e mensagens evidenciadas.

A partir da chegada dos álbuns em Goiânia, a equipe do acervo fotográfico do MIS-GO prosseguiu a pesquisa histórica, possibilitando a catalogação informatizada e a digitalização das imagens. Tornaram-se disponíveis 880 novos registros no banco de dados, para consulta a estudantes, 
professores, pesquisadores e usuários da comunidade. $\bigcirc$ desenvolvimento de ações museológicas de comunicação intensificou-se, visto que a realização do projeto proporcionou a preservação da rica coleção de álbuns e ampliou a possibilidade de pesquisa em diferentes áreas do conhecimento: história social, arquitetura, urbanização, sociologia do trabalho, história cultural, história da fotografia, entre outras.

\section{REFERÊNCIAS}

CARVALHO, Vânia Carneiro de; LIMA, Solange Ferraz de. Fotografias como objeto de coleção e de conhecimento: por uma relação solidária entre pesquisa e sistema documental.Anais do Museu Histórico Nacional, Rio de Janeiro, v. 32, p. 15-32, 2000.

FUNARTE-IBAC; et al. Manual de catalogação de documentos fotográficos: versão preliminar. Rio de Janeiro: Funarte-IBAC; Fundação Biblioteca Nacional; Museu Histórico Nacional; Museu Imperial de Petrópolis; CPDOC-FGV, 1993.

HENDRIKS, Klaus; et al. Fundamentals of photographic conservation: a study guide. Ottawa: National Archives of Canada, 1991.

LAVÉDRINE, Bertrand. A guide to preventive conservation of photograph collections. Los Angeles: Getty Conservation Institute, 2003.

MENESES, Ulpiano Toledo Bezerra de. Memória e cultura material: documentos pessoais no espaço público. Estudos históricos, Rio de Janeiro, v. 11, n. 21, p. 89-104, 1998.

MUSEUMS AND GALLERIES COMISSION CONSERVATION UNIT. The science for conservators: adhesives and coatings. v. 3. London: Routledge, 1992.

MUSEUMS, LIBRARIES AND ARCHIVES COUNCIL. Conservação de coleções: Museums, Libraries and Archives Council. São Paulo: Edusp, 2005 (Museologia: roteiros práticos, 9).

PAVÃO, Luis. Conservação de fotografias: o essencial. In: FUNARTE. Cadernos Técnicos de Conservação Fotográfica, 3.3. ${ }^{a}$ ed. rev. Rio de Janeiro: Funarte, 2004. p. 7-12.

Conservação de coleções de fotografia. Lisboa: Dinalivro, 1997.

REILLY,James M. IPI storage guide for acetate film. Rochester: Kodak, 1993.

RITZENTHALER, Mary Lynn. Archives and manuscripts: administration of photographic collections. Chicago: Society of American Archivists, 1984.

Artigo apresentado em 4/2007. Aprovado em 5/2007. 